Review

\title{
Biomass-Derived Production of Itaconic Acid as a Building Block in Specialty Polymers
}

\author{
Bernadette-Emóke Teleky ${ }^{1}$ and Dan Cristian Vodnar ${ }^{2, *(1)}$ \\ 1 Institute of Life Sciences, University of Agricultural Sciences and Veterinary Medicine, Calea Mănăştur 3-5, \\ 400372 Cluj-Napoca, Romania; bernadette.teleky@usamvcluj.ro \\ 2 Faculty of Food Science and Technology, Institute of Life Sciences, University of Agricultural Sciences and \\ Veterinary Medicine of Cluj-Napoca, Calea Mănăștur 3-5, 400372 Cluj-Napoca, Romania \\ * Correspondence: dan.vodnar@usamvcluj.ro; Tel.: +40-747-341-881
}

Received: 10 May 2019; Accepted: 7 June 2019; Published: 11 June 2019

\begin{abstract}
Biomass, the only source of renewable organic carbon on Earth, offers an efficient substrate for bio-based organic acid production as an alternative to the leading petrochemical industry based on non-renewable resources. Itaconic acid (IA) is one of the most important organic acids that can be obtained from lignocellulose biomass. IA, a 5-C dicarboxylic acid, is a promising platform chemical with extensive applications; therefore, it is included in the top 12 building block chemicals by the US Department of Energy. Biotechnologically, IA production can take place through fermentation with fungi like Aspergillus terreus and Ustilago maydis strains or with metabolically engineered bacteria like Escherichia coli and Corynebacterium glutamicum. Bio-based IA represents a feasible substitute for petrochemically produced acrylic acid, paints, varnishes, biodegradable polymers, and other different organic compounds. IA and its derivatives, due to their trifunctional structure, support the synthesis of a wide range of innovative polymers through crosslinking, with applications in special hydrogels for water decontamination, targeted drug delivery (especially in cancer treatment), smart nanohydrogels in food applications, coatings, and elastomers. The present review summarizes the latest research regarding major IA production pathways, metabolic engineering procedures, and the synthesis and applications of novel polymeric materials.
\end{abstract}

Keywords: itaconic acid; biotechnology; biosynthetic pathways; Aspergillus terreus; polymers; hydrogels; drug delivery

\section{Introduction}

The use of non-renewable petrochemicals still leads today's petrochemicals industry, while biomass is the only renewable source of organic carbon on Earth. Organic acid production through microbial fermentation of different biomass wastes can play an essential role in the production of biochemical building-blocks or even bioactive compounds [1-4]. Isikgor \& Becer [5] have recently presented over 200 significant compounds derived from different biomass sources and structures with pretreatment methods that can also reduce the production costs of chemicals and polymers.

Lignocellulosic biomass such as energy crops, agricultural and forest management residues, and municipal wastes are versatile renewable energy sources [6]. They can potentially replace fossil fuels in power and heat generation, and natural gases in the production of bio-based chemicals. A recent review analyzed the present situation of bio-based chemical production through biological and chemical pathways, presenting 435 chemicals and materials obtained from renewable resources [7]. Biomass and biomass-derived wastes have the potential to provide low-cost sources of sugar and could be the best substitute for non-renewable petrochemicals. 
A current major problem is the high amount of plastics present in the environment and their role in environmental pollution, since they don't degrade under natural circumstances. These plastics are mostly composed of synthetic polymers derived mainly from petrochemicals. A solution for this never-ending problem is the exploration of alternative bio-based and biodegradable plastics like biosynthetic polymers [8], polylactic acid (PLA), thermoplastic starch (TPS) or even natural polyesters like polyhydroxyalkanoates (PHA) $[9,10]$.

One of the most important classes of compounds obtained from lignocellulose biomass are organic acids. Bio-based organic acids are products that are derived from different biomass sources, which are sustainable, cost-effective, and environmentally friendly. Among these, itaconic acid (IA), together with its derivatives, is an essential renewable chemical because it has various uses in the pharmaceutical and food industry, and also presents a feasible substitute for unsaturated acids like acrylic, methacrylic, maleic, fumaric acid and their derivatives [11-13]. Integration of IA in polymers is very efficient [14].

IA is an unsaturated dicarboxylic acid $\left(\mathrm{C}_{5} \mathrm{H}_{6} \mathrm{O}_{4}\right)$, also known as 2-methylenebutanedioic acid, propylene dicarboxylic acid, or 2-methylenesuccinic acid (Figure 1a,b). IA is highly soluble in water and alcohols [15], stable at average temperatures, and, being a weak acid, it is also stable in middle-basic, neutral and acidic conditions [16]. It has an appearance of white crystalline powder or crystals, and it is odor-free $[17,18]$. The variation of IA's functional groups makes it an efficient intermediate to produce different complex organic compounds. It can participate in a wide variety of reactions like esterification with alcohols, salt formation with metals, production of anhydride, polymerization, and additional reactions [19].<smiles>C=C(CC(=O)O)C(=O)O</smiles>

(a) Itaconic acid

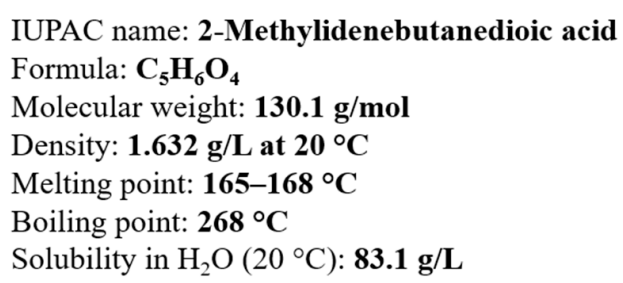<smiles></smiles>

Figure 1. The chemical structure (a), properties (b) and chemical synthesis from citric acid (c) $\Delta$ : heat input.

Baup S. discovered IA in 1837 as a product of thermal decomposition of citric acid [20], while Kinoshita was the first to report production of IA with Aspergillus itaconicus in 1931 [21]. Later, the focus for IA fermentation was shifted mostly to A. terreus strains. Nelson et al. [22] studied A. terreus NRRL strain 1960 and established a biotechnical process; while Eimhjellen et al. [19] studied the effect of different substrates (various sugars and alcohols) on IA production. Production with A. terreus NRRL 1960 in $20 \mathrm{~mL}$ media and 5\% substrate in $100 \mathrm{~mL}$ flasks resulted in the highest IA production with sucrose (57\%) and D-glucose (52\%). Other substrates like cellobiose $(41 \%)$, D-mannose $(32 \%)$, d-xylose (31\%), D-fructose (26\%) and glycerol (23\%) produced significant amounts of IA as well [23].

The initial industrial production of IA used a chemical approach, i.e., the pyrolysis of citric acid to itaconic anhydride, followed by the hydrolysis of the anhydride (Figure 1c) [20]. Alternative methods were decarboxylation of aconitic acid, dry distillation of anhydride, and oxidation of isoprene [24,25]. Due to the numerous steps and low production rates, the chemical synthesis of IA is not very effective in comparison with the biotechnological method [26]. 
Numerous reviews have summarized the attempts to improve the various IA production technologies $[27,28]$. Many researchers have actively evaluated different industrially significant microorganisms that synthesize IA [29,30], and also specific improvements through genetic engineering of various strains for higher IA production [31,32]. Due to the increased global marketing potential of IA, biotechnological production was also evaluated [33]. Different polyesters, bio-based resins, and other commodity materials were also highly considered [14,34], showing the increasing demand for IA yield improvement and for lower production costs. According to the US Department of Energy, IA is included in the top 12 building block chemicals, since it is a promising platform molecule with extensive applications $[35,36]$.

The production of IA (around 41,000 tons/year) takes place currently mainly in three countries: the USA, China, and India [11,36-38]. The high request for bio-based materials anticipates a further growth of $60 \%$ of the IA world market, predicted to surpass 216 million USD in 2020 [33,39]. Assuming that IA can replace polyacrylic acid, the market value would increase even more, and IA would become a valuable compound in the industrial biotechnology field $[30,40]$.

To compete with conventional chemical methods, bio-based processes yielding chemical building-blocks should have a production rate of $50 \mathrm{~g} / \mathrm{L}, 80 \%$ theoretical yield and a volumetric capacity of about $3 \mathrm{~g} / \mathrm{L}[35,41]$. Biorefinery improvement has two key roles: an economic goal by decreasing the production price, and a strategic goal to supplement the petroleum-based industry by exploiting the renewable biomass residues [41].

The aim of this review is to summarize recent advancements in biotechnological IA production in terms of substrates and optimal conditions used, the progress made in metabolic engineering and the state-of-the-art in major IA applications.

\section{IA Synthesis by Microbial Fermentation}

The most commonly used fungi for IA production are the Aspergillus species [42,43], and mainly A. terreus $[37,44,45]$; other microorganisms are also able to produce IA, e.g., the filamentous fungus Ustilago maydis $[29,46,47]$ and even species of Pseudozyma, although only P. antarctica was shown to produce a small quantity of IA. Using P. antarctica Y-7808 under nitrogen-limited conditions, the IA production on different carbon sources was $11 \mathrm{~g} / \mathrm{L}$ for fructose, $10 \mathrm{~g} / \mathrm{L}$ for glucose, $8-9 \mathrm{~g} / \mathrm{L}$ for sucrose and $6-7 \mathrm{~g} / \mathrm{L}$ for maltose [48].

\subsection{Biosynthetic Pathways}

The IA biosynthesis in A. terreus takes place under aerobic conditions and begins with glucose, which is transformed to pyruvate via glycolysis (Figure 2a). Pyruvate is metabolized to acetyl-CoA, and a carbon dioxide molecule is released. A partial transformation of acetyl-CoA to oxaloacetate occurs with the inclusion of the formerly liberated carbon dioxide molecule prior to metabolizing acetyl-CoA in the mitochondrion. From oxaloacetate and acetyl-CoA, citrate and cis-aconitate are produced in the citric acid, also known as tricarboxylic acid (TCA) cycle. Next, the mitochondrial tricarboxylate transporter ( $m t t A$ gene) transfers cis-aconitate in the cytosol. There, cis-aconitate decarboxylase (encoded by the cadA gene) facilitates the production of IA by discharging carbon dioxide [49-51]. Simultaneously, the facilitator superfamily protein ( $m f_{s} A$ gene) transfers IA outside the cell. Therefore, the genes that contribute to the IA production are $c a d A, m t t A$, and $m f s A$. 


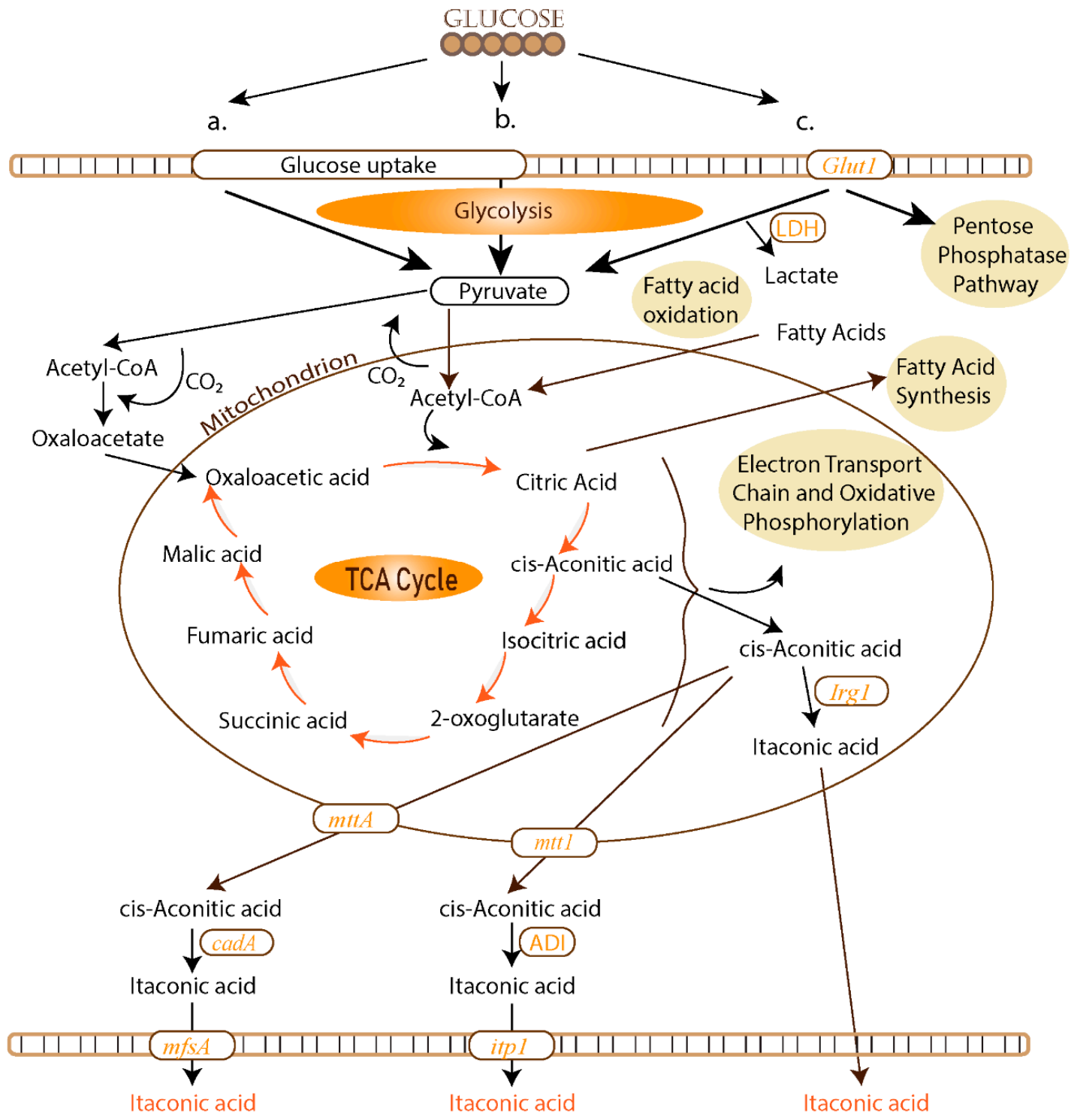

Figure 2. Biological pathway of IA in (a) A. terreus, (b) U. maydis; and (c) in macrophages.

$U$. maydis presents an alternative biosynthetic pathway for IA production (Figure $2 \mathrm{~b}$ ) that shows a different course mainly because it does not express the cadA gene. The mitochondrial tricarboxylate transporter ( $m t t 1$ gene) secretes cis-aconitate to the cytosol, where it is decarboxylated to itaconate by the cytosolic aconitate- $\Delta$-isomerase (ADI). Itaconate is afterwards excreted from the cytosol to the external medium through the cell wall by the membrane transport protein ITP1 (major facilitator) [47].

IA, defined as an essential anti-microbial agent, is also produced in mammalian macrophages (Figure 2c) using the immunoresponsive gene 1 (Irg1) which codes for the enzyme (cis-aconitate decarboxylase) responsible for IA production $[52,53]$. The production of IA in macrophages takes place via a TCA intermediate during decarboxylation of cis-aconitate [54,55].

\subsection{IA Fermentation Using Different Substrates and A. terreus Strains}

The principal producer of IA is A. terreus. So far, many research studies have been published on IA fermentation with different strains of this fungus (Table 1). A wide variety of Aspergillus species are used in the production of many primary and secondary metabolites (e.g., lovastatin, terrein, cyclosporine, and asperfuranone). A. terreus is a saprotrophic fungus inhabiting soil and 
has both damaging (adverse health effects in plant crops and humans) and favorable effects (from a biotechnological perspective) [56].

One of the limiting aspects of IA production is the high cost of the carbon source [37]. Glucose is the most frequently used substrate, however, not the cheapest carbon source [36].

Due to the high amount of different lignocellulose-rich waste materials providing an energy potential of around 12-120 EJ (exajoules) [57-59], these possible sources of raw materials have recently received special attention. Promising substrates are various lignocellulose hydrolysates (i.e., wheat bran, beech wood, rice husk), starch and molasses, which could be a good alternative source of glucose. A recent case study of itaconate synthesis from pretreated and hydrolyzed beech wood established a reasonable production yield, practicability, operation mode, and the favored microorganism. The final yield of obtained IA was with A. terreus $0.35 \mathrm{~g} \mathrm{IA} / \mathrm{g}$ glucose, and with the genetically engineered $U$. maydis $0.48 \mathrm{~g} \mathrm{IA} / \mathrm{g}$ glucose. In this study, the genetically enhanced $U$. maydis was the preferable microorganism for IA production from pretreated biomass due to medium contamination tolerance. On the grounds of advantages and drawbacks of biomass transformation to itaconate, future improvements were also highlighted [60].

Instead of glucose, the use of starch-rich wastes (corn, rice, and potato starch) as substrates with different fungi provide enhanced IA production [61]. In a recent study, the enzymatically hydrolyzed substrates resulted in $180 \mathrm{~g} / \mathrm{L}$ glucose. With $A$. terreus strain, the highest IA production obtained was $\mathrm{C} 1$ $(30.8 \mathrm{~g} / \mathrm{L})$ and $\mathrm{C} 2(23.4 \mathrm{~g} / \mathrm{L})$ with potato as waste [36]. Cornstarch is another very pure, economical, and balanced carbon source in mass production. Because it is an outstanding substrate, it was also used for fermentation with A. terreus TN-484 in a hydrolyzed form, with $>60 \mathrm{~g} / \mathrm{L}$ IA yield. By overexpressing the glucoamylase gene in a genetically engineered $A$. terreus, the production rate increased to $77.6 \mathrm{~g} / \mathrm{L}$ [62].

A possible substrate for IA production with two strains of $A$. terreus (ATCC 7860 and ATCC 10020) is pretreated rice husk hydrolysate [63]. After rice husk pretreatment, the concentration of monosaccharides: glucose, xylose, and arabinose decreased from $35.66 \%, 14.79 \%$ and $3.61 \%$ to $17.18 \%$, $0 \%$ and $0 \%$, respectively. Using different concentrations of these monosaccharides, six different media were prepared and subjected to fermentation for the optimization of IA production. The results indicated that rice husk can be used through acidic phosphoric hydrolysis with $A$. terreus and produce $1.9 \mathrm{~g} / \mathrm{L}$ IA from $35 \mathrm{~g} / \mathrm{L}$ glucose. These results indicate that the favored source of carbon in IA production is glucose. In a wheat bran hydrolysate, $A$. terreus CICC 40,205 was used in optimized conditions (pH $7,32{ }^{\circ} \mathrm{C}$ ) and a final concentration of $49.65 \mathrm{~g} / \mathrm{L}$ IA was obtained [64].

By using second generation feedstock (wheat chaff) and alkaline pretreatment $(\mathrm{NaOH})$ following enzymatic saccharification (carbohydrate polymer transformation in free monomeric sugars) with $A$. terreus DSM 23,081, the production of IA was $27.7 \mathrm{~g} / \mathrm{L}[45,65]$. Using the same filamentous fungus strain, but glucose as substrate, the outcome was $86.2 \mathrm{~g} / \mathrm{L}$ itaconate [66]. Saha and Kennedy analyzed six distinctive $A$. terreus strains and also different sugars as substrates (glucose, xylose, arabinose, and mixed sugars) [67]. The highest IA production was $47.9 \mathrm{~g} / \mathrm{L}$ using glucose as substrate and A. terreus NRRL 1961 strain; from xylose, the highest quantity was $36.0 \mathrm{~g} / \mathrm{L}$ IA with A. terreus DSM 23,081 strain.

Hevekerl et al. studied the effect of $\mathrm{pH}$ on IA yield [68], and the highest concentration of itaconate achieved was $146 \mathrm{~g} / \mathrm{L}$ at $\mathrm{pH} 3$ with $A$. terreus DSM 23,081 strain. The initial $\mathrm{pH}$ has to be low for the microorganisms to achieve IA production capability [19]. Using optimized conditions, the concentration obtained by Larsen and Eimhjellen [23], was $129 \mathrm{~g} / \mathrm{L}$, which is a very high concentration compared to the results of other investigations (Table 1).

As observed in various studies, different parameters influence the final production of IA: the used microorganisms, temperature, medium concentrations, the initial $\mathrm{pH}$ and the variation of $\mathrm{pH}$ values through the fermentation process, oxygen supply and also the formation of side products $[68,69]$. Therefore, the creation of competent microbial cell factories for IA production through genetic engineering should bring substantial benefits for the production levels $[62,70]$. 
Table 1. Fermentation parameters and yields using different $A$. terreus strains.

\begin{tabular}{|c|c|c|c|c|c|c|c|c|}
\hline Substrate & A. terreus & IA $[\mathrm{g} / \mathrm{L}]$ & $\mathrm{pH}$ & $\mathrm{T}\left[{ }^{\circ} \mathrm{C}\right]$ & Method & $\begin{array}{c}\mathrm{OP} \\
{[\mathrm{g} / \mathrm{L} / \mathrm{h}]}\end{array}$ & $\begin{array}{c}\mathrm{Y} \\
{\left[\mathrm{g} / \mathrm{g}_{\mathrm{TS}}\right]}\end{array}$ & Ref. \\
\hline glucose & NRRL 1960 & $24.7-49.5$ & $1.8-2.0$ & 34 & $\mathrm{BF}$ & $0.33-0.44$ & N.A. & [22] \\
\hline $\begin{array}{l}\text { carbon } \\
\text { sources }\end{array}$ & NRRL 1960 & 129 & $2.1-6.0$ & N.A. & SF & N.A. & N.A. & [19] \\
\hline glucose & & & 2.5 & 35 & $\mathrm{BR}$ & N.A. & N.A. & [71] \\
\hline \multirow{4}{*}{ corn starch } & \multirow{4}{*}{ TN-484 } & 62 & 1.5 & 30 & \multirow{4}{*}{ SF/ALB } & \multirow{4}{*}{ N.A. } & \multirow{4}{*}{ N.A. } & \multirow{4}{*}{ [72] } \\
\hline & & 61 & 2.0 & 30 & & & & \\
\hline & & 59 & 2.5 & 30 & & & & \\
\hline & & 57 & 3.0 & 30 & & & & \\
\hline $\begin{array}{l}\text { Jathropa } \\
\text { seed cake }\end{array}$ & & 24.46 & 3.5 & 32 & SF & N.A. & N.A. & [73] \\
\hline \multirow{2}{*}{ glucose } & & 86.2 & \multirow{2}{*}{3.1} & \multirow{2}{*}{33} & \multirow{2}{*}{ STR } & 0.51 & 0.62 & \multirow{2}{*}[66]{} \\
\hline & & 90 & & & & N.A. & 0.58 & \\
\hline corn starch & CICC 40205 & 77.6 & 4.0 & 37 & SF & N.A. & N.A. & [62] \\
\hline \multirow{3}{*}{ glucose } & \multirow{3}{*}{ DSM 23081} & 129 & 3.1 & 33 & \multirow{3}{*}{ STR } & \multirow{3}{*}{ N.A. } & \multirow{3}{*}{ N.A. } & \multirow{3}{*}{ [68] } \\
\hline & & 87 & N.A. & N.A. & & & & \\
\hline & & 146 & 3.0 & N.A. & & & & \\
\hline rice husk & ATCC 10020 & 1.9 & 6.0 & 30 & SF & N.A. & N.A. & [63] \\
\hline wheat chaff & \multirow{2}{*}{ DSM 23081} & 27.7 & 3.1 & 33 & \multirow[t]{2}{*}{ SF } & 0.19 & 0.41 & \multirow[t]{2}{*}{ [45] } \\
\hline $\begin{array}{c}\text { artif. wheat } \\
\text { chaff }\end{array}$ & & 51.5 & 3.1 & 33 & & 0.31 & 0.59 & \\
\hline \multirow{2}{*}{ potato starch } & $\mathrm{C} 1$ & 30.8 & N.A. & 35 & \multirow{2}{*}{ SF } & \multirow{2}{*}{ N.A. } & \multirow{2}{*}{ N.A. } & \multirow{2}{*}{ [61] } \\
\hline & $\mathrm{C} 2$ & 23.4 & N.A. & N.A. & & & & \\
\hline wheat bran & CICC 40205 & 49.65 & 7.0 & 32 & SF & N.A. & N.A. & [74] \\
\hline mannose & \multirow{4}{*}{ NRRL 1971} & 36.4 & \multirow{5}{*}{3.1} & & & & 0.46 & \\
\hline glucose & & 42.6 & & 33 & SF & N.A. & & [30] \\
\hline xylose & & 30.5 & & & & & N.A. & \\
\hline arabinose & & 25.8 & & & & & & \\
\hline galactose & DSM 23081 & 9.1 & & & & & & \\
\hline & & 129 & 3.0 & & & 0.61 & 0.57 & \\
\hline glucose & DSM 23081 & 138 & 3.2 & 35 & SGR & 0.82 & N.A. & [75] \\
\hline & & 162 & 3.4 & & & 0.99 & 0.46 & \\
\hline & & 150 & 3.0 & & STR & N.A. & 0.56 & \\
\hline glucose & DSM 23081 & 70 & 3.1 & 33 & $\mathrm{Fl}$ & N.A. & N.A. & [76] \\
\hline glucose & DSM 23081 & 105 & 3.1 & 33 & & & & \\
\hline glucose & NRRL 1960 & 51.9 & & & & & & \\
\hline xylose & DSM 23081 & 38.7 & 3.1 & 33 & SF & N.A. & N.A. & [77] \\
\hline arabinose & NRRI 1961 & 34.8 & & & & & & \\
\hline GXA & & 33.2 & & & & & & \\
\hline
\end{tabular}


Table 1. Cont.

\begin{tabular}{|c|c|c|c|c|c|c|c|c|}
\hline Substrate & A. terreus & IA $[\mathrm{g} / \mathrm{L}]$ & $\mathrm{pH}$ & $\mathrm{T}\left[{ }^{\circ} \mathrm{C}\right]$ & Method & $\begin{array}{c}\mathrm{OP} \\
{[\mathrm{g} / \mathrm{L} / \mathrm{h}]}\end{array}$ & $\begin{array}{c}Y \\
{\left[g / g_{T S}\right]}\end{array}$ & Ref. \\
\hline glucose & NRRL 1960 & 73.6 & 3.0 & 33 & $\mathrm{BF}$ & N.A. & 0.85 & [44] \\
\hline fruit waste & \multirow{2}{*}{ SKR10 } & 20 & \multirow{2}{*}{3.0} & \multirow{2}{*}{34} & \multirow{2}{*}{ SF } & N.A. & 0.22 & \multirow{2}{*}[78]{} \\
\hline Corn starch & & $28.5-31.0$ & & & & N.A. & 0.26 & \\
\hline
\end{tabular}

\subsection{IA Fermentation with Other Microorganisms}

The primary production of IA is currently done with $A$. terreus strains, but other microorganisms like Ustilago sp. [47,79], Candida sp. [80] and Pseudozyma sp. also produce IA [48] (Table 2).

Table 2. Fermentation parameters and yields using different methods and microorganisms.

\begin{tabular}{|c|c|c|c|c|c|c|c|c|}
\hline Substrate & Strain & IA $[\mathrm{g} / \mathrm{L}]$ & $\mathrm{pH}$ & $\mathrm{T}\left[{ }^{\circ} \mathrm{C}\right]$ & Method & $\begin{array}{c}\mathrm{OP} \\
{[\mathrm{g} / \mathrm{L} / \mathrm{h}]}\end{array}$ & $\begin{array}{c}\mathbf{Y} \\
{[\mathrm{g} / \mathrm{gTS}]}\end{array}$ & Ref. \\
\hline glucose & $\begin{array}{l}\text { Yarrowia } \\
\text { lipolytica }\end{array}$ & 4.6 & $3.5-5.0$ & 28 & $\mathrm{BR}$ & 0.045 & 0.058 & [49] \\
\hline glucose & Candida sp. & $30-35$ & 3 & 26 & flask & N.A. & N.A. & [80] \\
\hline glucose & \multirow{2}{*}{$\begin{array}{c}C . \\
\text { glutamicum } \\
\text { strains }\end{array}$} & $1.4-3.6$ & \multirow{2}{*}{7.0} & \multirow{2}{*}{30} & \multirow{2}{*}{$\mathrm{BSF}$} & \multirow{2}{*}{ N.A. } & 0.011 & \multirow{2}{*}{ [81] } \\
\hline urea & & $13.3-59.0$ & & & & & 0.23 & \\
\hline glycerol & $\begin{array}{l}\text { U. vetiveriae } \\
\text { TZ1 }\end{array}$ & 34.7 & 6.5 & N.A. & SF & 0.09 & N.A. & [82] \\
\hline glucose & $\begin{array}{l}\text { U. maydis } \\
\text { MB } 215\end{array}$ & 4 & 6 & 30 & $\mathrm{CF}$ & 0.8 & N.A. & [46] \\
\hline potato starch & U. maydis & 34.52 & N.A. & N.A. & N.A. & N.A. & N.A. & [61] \\
\hline glucose & $\begin{array}{l}\text { U. maydis } \\
\text { MB215 }\end{array}$ & 20 & N.A. & 30 & SF & 0.27 & 0.17 & [79] \\
\hline cellobiose & $\begin{array}{l}\text { U. maydis } \\
\text { strains }\end{array}$ & N.A. & 6.5 & 30 & SF & N.A. & N.A. & [83] \\
\hline glycerol & \multirow{3}{*}{ Eng. E. coli } & 22 & \multirow{3}{*}{$5-5.5$} & \multirow{3}{*}{37} & \multirow{3}{*}{ BSF } & 0.6 & 0.55 & \multirow{3}{*}{ [74] } \\
\hline xylose & & 20 & & & & 0.6 & 0.51 & \\
\hline glucose & & 18 & & & & 0.43 & 0.36 & \\
\hline \multirow{2}{*}{ glucose } & \multirow{2}{*}{ E. coli strains } & 2.27 & N.A. & 37 & SF & N.A. & 0.77 & \multirow{2}{*}{ [84] } \\
\hline & & 32 & N.A. & 30 & $\mathrm{BR}$ & N.A. & 0.68 & \\
\hline starch & E. coli & $0.15-0.62$ & 6.8 & 28 & $\mathrm{JF}$ & N.A. & N.A. & [85] \\
\hline glucose & $\begin{array}{l}\text { A. niger } \\
\text { strains }\end{array}$ & 26.2 & 3.5 & 33 & $\mathrm{BF}$ & 0.35 & N.A. & [43] \\
\hline glucose & $\begin{array}{l}\text { A. niger } \\
\text { strains }\end{array}$ & $0.26-0.29$ & 3.5 & 33 & $\mathrm{BF}$ & N.A. & N.A. & [86] \\
\hline sorbitol & $\begin{array}{l}\text { A. niger } \\
\text { CAD4 }\end{array}$ & $3-8$ & N.A. & 30 & flask & N.A. & N.A. & [87] \\
\hline $\begin{array}{l}\text { sorbitol + } \\
\text { xylose }\end{array}$ & $\begin{array}{l}\text { Eng. A. niger } \\
\quad+\text { cadA }\end{array}$ & 54.3 & N.A. & 30 & $\mathrm{~F}$ & N.A. & N.A. & [42] \\
\hline glucose & $\begin{array}{l}\text { Eng. A. niger } \\
\text { strains }\end{array}$ & $0.82-4.92$ & 3.1 & 35 & SF & N.A. & N.A. & [88] \\
\hline
\end{tabular}

$\overline{\mathrm{OP}}$-Overall productivity, Y-Yield, TS-total sugar, SF-shake flask, F-fermenter, CR-continuous fermenter, JF-jar fermenter, BF-benchtop fermenter, Br - bioreactor, Fl—flask, BSF-baffled shake flask, N.A.—not available.

Although $U$. maydis produces lower amounts of itaconate (maximum reported at $34.52 \mathrm{mg} / \mathrm{L}$ ) compared to $A$. terreus, this fungus integrates essential assets of yeast and filamentous fungi, like the growth in a yeast-related morphology in haploid form of single cells. U. maydis MB 215 is an 
encouraging IA producer on pretreated lignocellulosic wastes (beech-wood). The production of IA was achieved predominantly on three differently pretreated substrates (enzymatically hydrolyzed cellulose, salt-assisted organic acid catalyzed cellulose and hydrolyzed hemicellulose), although genetic alteration could have the capacity to increase the produced quantity [36].

Tabuchi et al. [80] could not identify the used Candida yeast strain, but with $\mathrm{pH}$ values above 3 , the preliminary results showed that IA production was within the range of $30-35 \mathrm{mg} / \mathrm{mL}$.

IA production with $P$. antarctica NRRL Y-7808 in nitrogen-restricted growth conditions in culture flasks was $30 \mathrm{~g} / \mathrm{L}$, starting from $80 \mathrm{~g} / \mathrm{L}$ glucose. Other Pseudozyma strains did not produce IA, so this is not a common feature of this yeast [48].

The global development of biodiesel production results in high raw glycerol content, a primary byproduct of biodiesel manufacturing [89]. Through glycerol fermentation, numerous valuable compounds can be obtained [90-92]. Zambanini et al. [82] studied the production of IA from glycerol with the $U$. vetiveriae strain TZ1 and also with the same strain but through overexpression of ria1 and $m t t 1$ genes. Quantities achieved were above $34.7 \mathrm{~g} / \mathrm{L}$ itaconate from $196 \mathrm{~g} / \mathrm{L}$ glycerol using a medium optimization in shake flasks buffered with $\mathrm{CaCO}_{3}$.

\subsection{Metabolic Engineering}

Metabolic engineering has unlocked an innovative path and is used to improve the genetic and regulatory mechanisms inside cells to expand IA production [49,62,93,94].

Through genetically engineered $A$. terreus strains, there is a possibility to achieve a considerable shortening of the fermentation process during the integration of the two phases, saccharification and fermentation, into one phase [85].

Using modified $A$. terreus, liquefied corn starch could be used more effectively for IA production compared to the wild-type strain [5]. At optimum conditions, using the most outstanding genetically engineered IA producer XH86-8, itaconate was produced at 77.6 g/L (after three days of fermentation) which is approaching the industrial production yields [85,88].

The fast-developing microorganism E. coli is able to be a substitute for IA production with fewer by-products. In E. coli, with the recognition of common targets, a frequent problem can be solved, namely the chemical resistance of the microorganisms [95].

Several metabolically engineered E. coli strains have been reported recently $[64,84,85]$. The expression of $\alpha$-amylase from Streptococcus bovis in E. coli produced after $69 \mathrm{~h}$ a quite low amount of $0.15 \mathrm{~g} / \mathrm{L}$ itaconate using starch as substrate [85]. A production plasmid (pCadCS) that incorporates the codon-optimized (improved protein expression) cadA genes (A.terreus) and gltA (Corynebacterium glutamicum) were introduced in E. coli [84]. This strain produced $32 \mathrm{~g} / \mathrm{L}$ itaconate and a maximum yield of $0.77 \mathrm{~mol} /(\mathrm{mol}$ glucose). The whole cell bioconversion of citrate proposed by Kim et al. [96] can diminish the time and cost of itaconate production. Cys-aconitate decarboxylase (cadA) gene from $A$. terreus and acn from C. glutamicum with an improved expression at optimal conditions ( $\mathrm{pH} 5.5$ and $35^{\circ} \mathrm{C}$ ) produced $41.6 \mathrm{~g} / \mathrm{L}$ itaconate. To achieve further increase in IA production using E. coli, glycerol was used as substrate, resulting in $43 \mathrm{~g} / \mathrm{L}$ itaconate [97]. Compared to fungi, E. coli presents many advantages, specifically faster growth, easier handling, and accessible gene manipulation $[85,97,98]$.

A. niger is an exceptional fungus in biorefinery usage since it can use a variety of substrates. A. niger is found to produce high quantities of citrate $(180 \mathrm{~g} / \mathrm{L})$. Moreover, it is a promising strain in the production of itaconate as well. Through strain engineering and the application of a low-pH-induced-promoter that improves gene expression, Pgas in A. niger H915-1, $4.92 \mathrm{~g} / \mathrm{L}$ IA was produced [88].

In $A$. niger with the overexpression of $c a d A$ or $m t t A$ genes from $A$. terreus and lowering the dissolved oxygen levels in the bioreactors, IA production increased from $0.8 \mathrm{~g} / \mathrm{L}$ to $2.5 \mathrm{~g} / \mathrm{L}$ [99]. With oxygen levels at $10 \%$, the production of IA in $A$. terreus was $52.9 \mathrm{~g} / \mathrm{L}$, but with the expression of cadA gene from A. terreus in $A$. niger, the IA production was just $0.7 \mathrm{~g} / \mathrm{L}$ [51]. The similar outcome obtained with the expression of the cadA gene in $A$. niger led to an increase from $0.05 \mathrm{~g} / \mathrm{L}$ to $7.1 \mathrm{~g} / \mathrm{L}$ IA production [42]. 
Therefore, the expression of the cadA gene in A. niger and through process optimization, IA production is achievable, but with the need for further studies to obtain higher yields [100].

\subsection{Consolidated Bioprocessing}

Compared to fossil oil, bio-catalytic conversion of cellulosic biomass is still more expensive for producing various compounds. A new process proposed to diminish these costs is consolidated bioprocessing (CBP) — which includes all three processes (cellulase production, hydrolysis of cellulose and fermentation of discharged sugars) in one step, or other pretreatment methods that apply fewer steps [101,102]. Antonov et al. [103] studied different cellulase producers and chose the most effective ones for IA production with $A$. terreus. Possible choices for cellulase production were Trichoderma reesei and Penicillium verruculosum. Although the observed faster cellulase production was with T. reesei; the overall results showed that $P$. verruculosum was a better choice when applying CBP, with higher carbon release rate and better cellulose digestibility.

Geiser et al. used the plant pathogen $U$. maydis MB215 strains [83] due to their special carbohydrate-active enzymes (CAZymes) that can degrade lignocellulose. These enzymes can be synthetically stimulated in the course of industrial development. In the production of itaconate, erythritol, hydroxyparaconate, and malate, different $U$. maydis strains have been used [104-106].

As future perspectives, investigation regarding new processes and strain developments to lower average costs while maintaining good yields of IA production is essential.

\subsection{Recovery and Purification of IA}

Improvements in the recovery and purification of IA are primary challenges in the advancement of biorefinery procedures [107]. The produced broth after IA fermentation contains residues, biomass, and other components, including organic acids [108]. The first step of IA recovery is the elimination of biomass and subsequently, the concentration and purification of IA. The primary separation and purification techniques used are precipitation, crystallization, adsorption, filtration, electrodialysis, and reactive extraction (Table 3 ).

Table 3. IA recovery method examples and main process disadvantages

\begin{tabular}{|c|c|c|c|c|}
\hline Method & Media & Yield [\%] & Disadvantage & Ref. \\
\hline Crystallization & FB & 80 & $\begin{array}{l}\text { - high thermal energy input required } \\
\text { - reduced final purity }>\text { additional } \\
\text { purification step }\end{array}$ & [37] \\
\hline Crystallization & FB & 51 & $\begin{array}{c}\text { - low yield } \\
\text { - high thermal energy input required }\end{array}$ & {$[109]$} \\
\hline Crystallization & FB & 23 & $\begin{array}{c}\text { - low yield } \\
\text { - change in fermentation temperature }\end{array}$ & {$[110]$} \\
\hline Adsorption & AS & 100 & - high waste-water quantity & {$[107]$} \\
\hline $\begin{array}{c}\text { Reactive } \\
\text { extraction/back } \\
\text { extraction/pH- shift } \\
\text { crystallization }\end{array}$ & FB & 99 & - $\mathrm{NaCl}$ salt by-product formation & {$[111]$} \\
\hline Reactive extraction & AS & 94.7 & - decreased toxicity due to usage of vegetable oil & {$[112]$} \\
\hline Back extraction & & 80 & $\begin{array}{l}\text { - high energy demand } \\
\text { - unwanted side products }\end{array}$ & [113] \\
\hline Reactive extraction & FB & 91 & - mass transfer area limitations & [76] \\
\hline Reactive extraction & AS & 80 & - process under study & {$[114]$} \\
\hline Electrodialysis & AS & 50 & $\begin{array}{c}\text { - low efficiency } \\
\text { - competitive only with a yield of } 98 \%\end{array}$ & {$[115]$} \\
\hline
\end{tabular}

FB-Fermentation broth; AS-Aqueous solution. 
A recent techno-economic analysis revealed that the achievement of the lowest production cost is with the adsorption method, but the drawback is the high amount of used water. Crystallization has a low yield of recovered IA, while requiring many steps and a high energy input. Electrodialysis and extraction need a lower energy input than crystallization but have higher costs. Extraction produces high amounts of wastewater, and electrodialysis consumes much energy [28].

As a conclusion, the technical feasibility of recovery and purification of IA is an essential challenge for achieving a high efficiency process.

\section{Major Applications of IA}

Due to environmental problems with current plastics, producing degradable polymers and elastomers from bio-renewable resources is of significant interest [116,117]. The U.S. Department of Energy includes IA as one of the 12 building blocks that can be transformed into varied high-value bio-based chemicals or materials from biomass (Figure 3) $[35,118,119]$. Because of the development of biotechnological techniques and cost reductions (price $<1 \mathrm{US} \$ / \mathrm{kg}$ ), IA became a prospective commodity chemical [120].

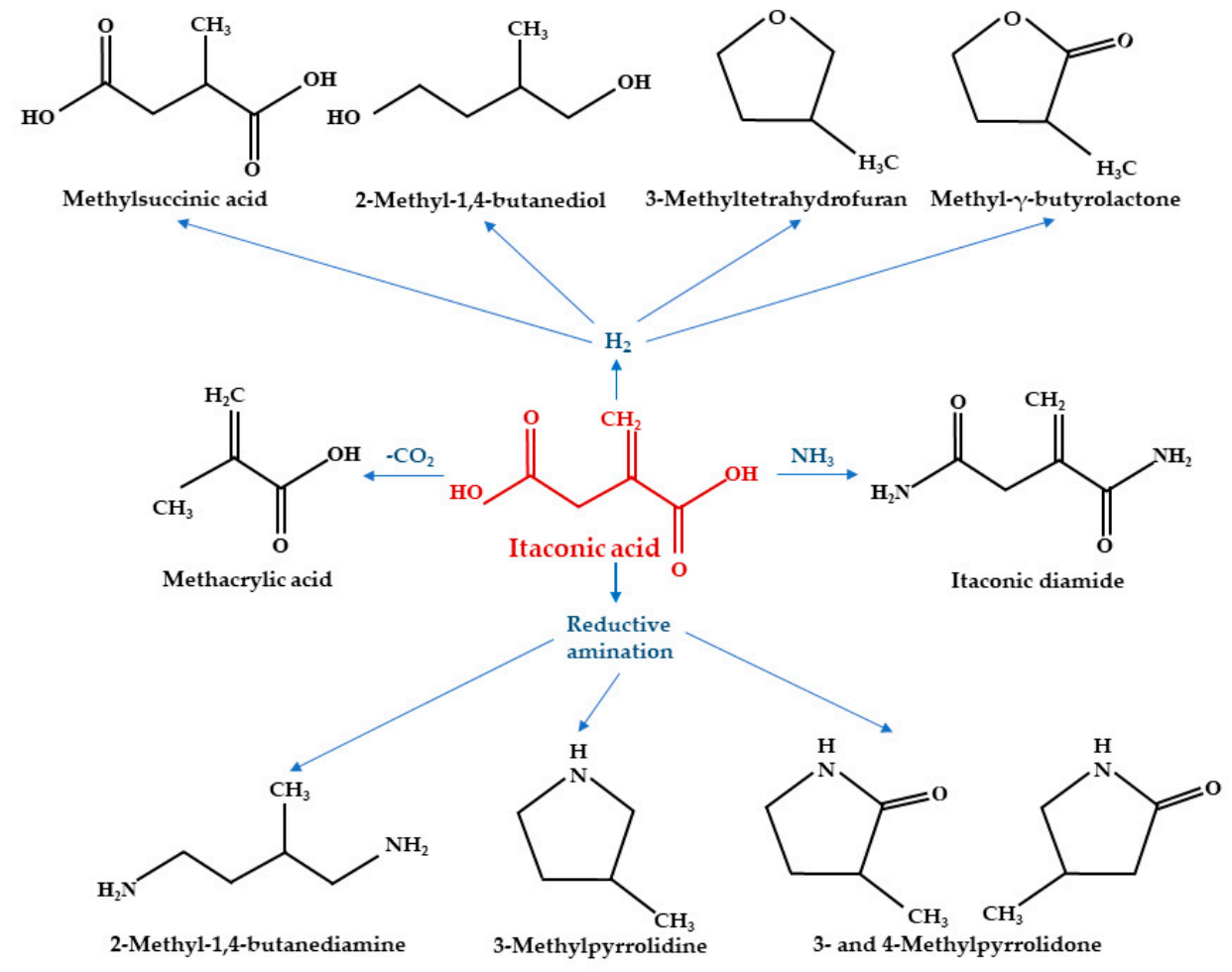

Figure 3. IA conversion into profitable derivatives.

Worldwide, IA primary usage is in styrene-butadiene rubber (SBR) latexes (44\%), synthetic latex $(9 \%)$, superabsorbent polymers $(8 \%)$, chelant dispersant agents $(7 \%)$, and in the production of methyl methacrylate $(4 \%)$. Other promising uses are unsaturated polyester resins, phosphate-free detergents, and in the food industry $[11,121]$. IA is an ionic hydrophilic co-monomer that enhances the demeanor of antimicrobial release and adjusts the polymer arrangement [122]. IA presents a viable solution to replace acrylic acid in biodegradable polymers, and to act as a substrate for the production of methacrylic acid $[17,123]$.

\subsection{IA in Polymeric Hydrogels}

Hydrogels have a structure composed of crosslinked polymer chains and can efficiently absorb considerable amounts of liquid when placed in aqueous solutions [124]. To qualify as a hydrogel, this 
hydrophilic polymer has to absorb at least $10 \%$ water [125]. These polymeric networks do not dissolve in water and are as flexible as the natural tissue. Hydrophilic gels exhibit specific traits of liquids like a high quantity of free liquid and solids with properly defined aspect. The soluble molecules can migrate throughout the gel. Due to the special properties of hydrogels, these polymers can be used in a wide diversity of products like super-absorbent polymers, tissue engineering, contact lenses, drug delivery, and biotechnological devices [126]. These polymers have the characteristics to increase, decrease, assign and discharge compounds when exposed to variations in particular environmental parameters such as temperature, ionic concentration, light intensity, $\mathrm{pH}$, pressure or even at the effect of particular biomarkers $[127,128]$. Two distinct hydrogel categories are known, synthetic and natural hydrogels. By crosslinking type, hydrogels can be chemical and physical (Figure 4). Crosslinked structures with stable connections are chemical hydrogels and those resulted from polymer chain entanglements or other physical interactions are physical hydrogels $[129,130]$. Hydrogels are frequently used in both medical biology [131] and biotechnology [132] due to their capability to absorb high amounts of liquid.

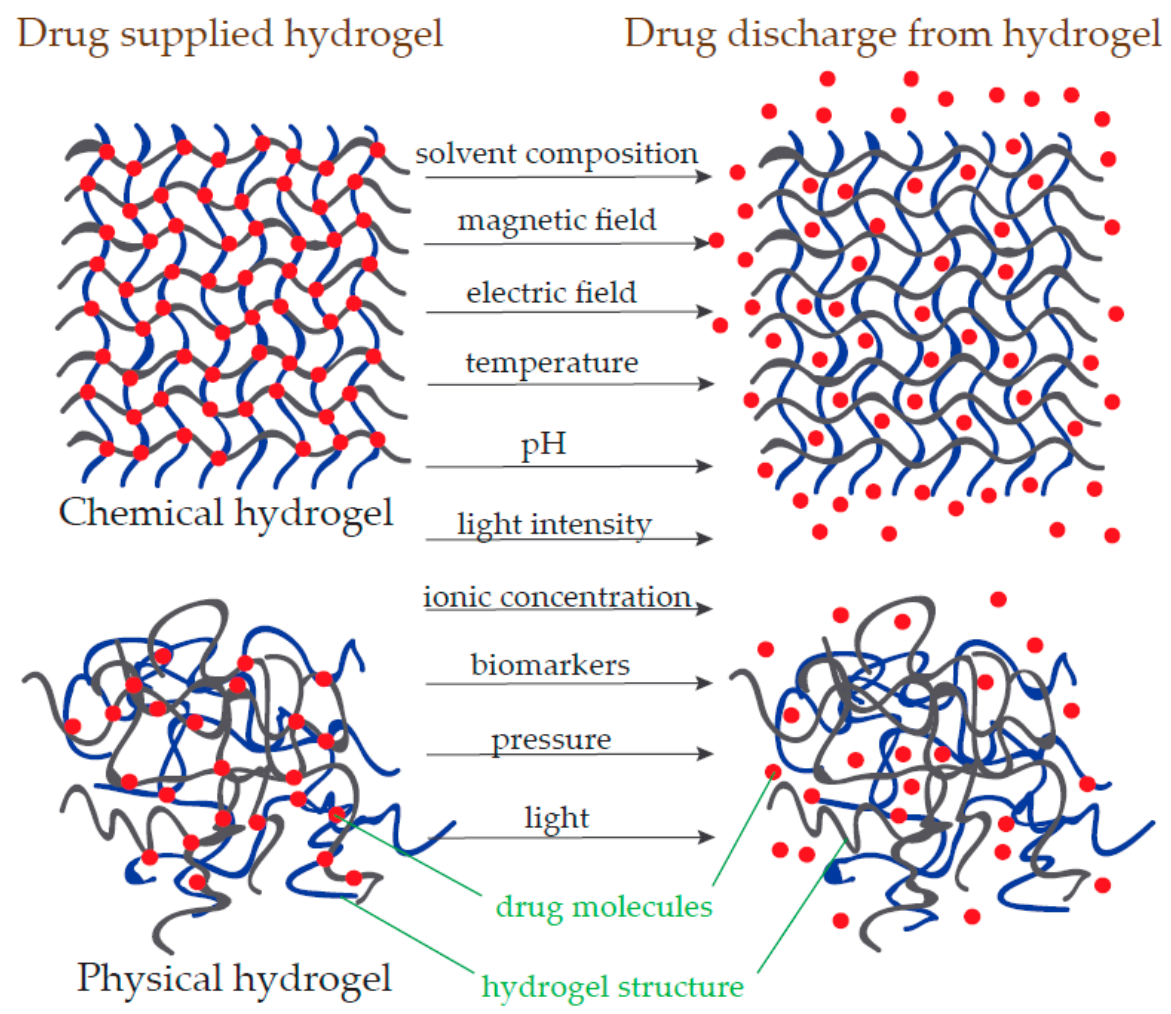

Figure 4. Hydrogel swelling and drug discharge with different physical or chemical stimulations.

Hydrogels made through polymerization as well as crosslinking of one or more polyfunctional monomers compose 3D networks. One possible natural source monomer is IA, together with its various esters, which can feasibly copolymerize with acrylamide and facilitate the swelling parameters of formed hydrogels. The highest swelling capability achieved with acrylamide and monomethoxyethyl itaconate hydrogel synthesized with a molar ratio of 70/30 was between 2,000 and 43,000\% [127].

Amonpattaratkit et al. [133] studied high- and low-molecular-weight gelatin-methacrylate and gelatin-IA crosslinkers percentages for hydrogel microstructure, the improvement of biodegradation, crosslinking behavior, and swelling ratio characteristics of hydrogels. The most significant swelling ratio established was of $38 \mathrm{~g} / \mathrm{g}$ with the $750 \mathrm{mM}$ high-molecular weight gelatin-IA hydrogel. In comparison, the low-molecular-weight hydrogel had a slightly higher swelling ratio and faster degradation. With the increase of IA content, the swelling ratio increased in both hydrogels. As an outcome, the highest biodegradation characteristic, featured by a decrease of physical coherence and swelling medium integrity, occurred with the gelatin-IA hydrogel LG1750 of low molecular weight. 


\subsubsection{IA Hydrogels Used in Water Decontamination}

An essential application of biodegradable acrylamide hydrogels that include IA and itaconate groups in super absorbent hydrogels is in water-decontamination due to outstanding features such as low-price, precise handling, and reusability [124,134,135]. Water pollution presents a major worldwide problem that has caused serious environmental and health effects [136].

One of the major pollutants released in water comprises metallic ions like $\mathrm{Fe}^{3+}, \mathrm{Pb}^{2+}, \mathrm{Cu}^{2+}$, $\mathrm{Cd}^{2+}, \mathrm{Fe}^{2+}, \mathrm{Cr}^{6+}, \mathrm{Ni}^{2+}, \mathrm{As}^{5+}, \mathrm{Cr}^{3+}, \mathrm{Zn}^{2+}$, and $\mathrm{Al}^{3+}$ that arise from various industries and as an outcome of great industrial developments. Research comprising different itaconate hydrogel structures Aam/IA-poly(acrylamide-co-itaconic acid), Aam/MEI-poly(acrylamide-co-monomethoxyethyl itaconate), and Aam/DEI-(acrylamide-co-dimethoxyethyl itaconate) (Figure 5a) determined the effective adsorption of the following metal ions $\mathrm{Cu}^{2+}, \mathrm{Fe}^{2+}, \mathrm{Fe}^{3+}, \mathrm{Pb}^{2+}, \mathrm{Ni}^{2+}$ and $\mathrm{Cd}^{2+}$. Single metal ion adsorption was more efficient for the Aam/MEI hydrogel with $\mathrm{Fe}^{3+}$ than the hydrogel with Aam/IA. The adsorption capability in the multi-element sample was maximum with all the ions absorbed for both hydrogels at a molar ratio of 80/20. The trend of ion adsorption in both hydrogels was identical: $\mathrm{Pb}^{2+}>\mathrm{Cu}^{2+}>\mathrm{Cd}^{2+}>\mathrm{Ni}^{2+}[132]$.

(a)
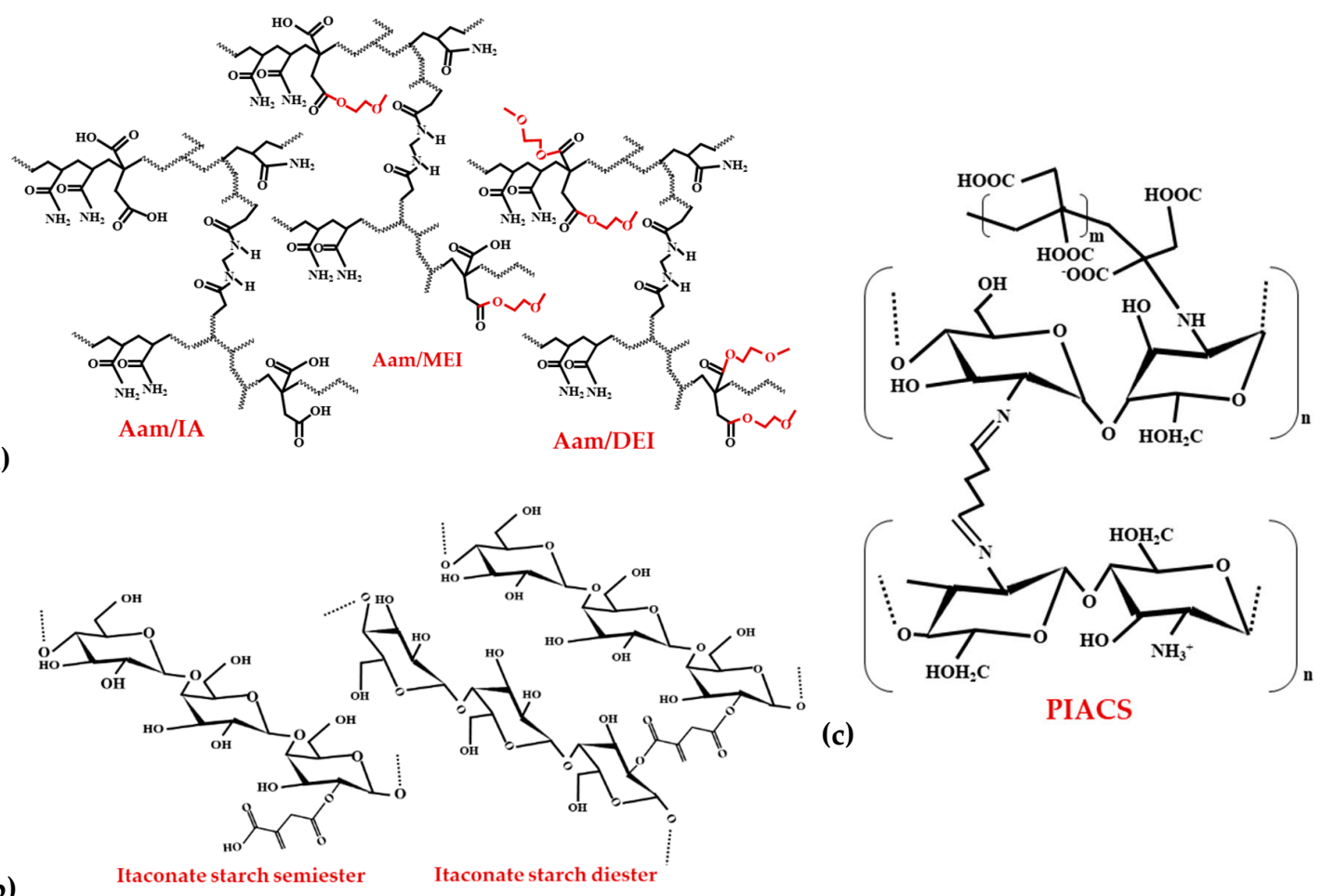

(b)

Figure 5. The chemical structure of IA synthesized hydrogels (a) Aam/IA, Aam/MEI, Aam/DEI (b) Itaconate starch semi- and diester (c) PIACS.

Starch is a naturally occurring biopolymer in high concentrations with several useful applications [137]. Soto et al. [138] generated starch-based superabsorbent materials with the natural compounds IA and maleic acid. The use of maleic acid presented high water solubility, and its use as an adsorbent was difficult. Itaconate starch mono- and diester presented competent crosslinking and substitution degrees. Itaconate starch diester hydrogel separated the metal ions $\mathrm{Pb}^{2+}, \mathrm{Cd}^{2+}, \mathrm{Ni}^{2+}$, and $\mathrm{Zn}^{2+}$ in the concentration of $11.24,7.11,5.10$, and $8.44 \mathrm{mg} / \mathrm{g}$ and with a retention capacity of 145.03 , $82.78,56.74,101.44 \mathrm{mg} / \mathrm{g}$ individually. Itaconate starch semiester hydrogel presented higher separation $(25.16,7.11,5.10,8.44 \mathrm{mg} / \mathrm{g})$ and retention capabilities $(506.44,89.09,72.99,92.89 \mathrm{mg} / \mathrm{g})$. Additionally, the same authors obtained novel hydrogels through graft copolymerization of starch with IA utilizing a redox system as the initiator $\left(\mathrm{KMnO}_{4} / \mathrm{NaHSO}_{3}\right)$ [139]. This hydrogel could separate higher amounts 
of the same metal ions $\mathrm{Pb}^{2+}, \mathrm{Cd}^{2+}, \mathrm{Ni}^{2+}$, and $\mathrm{Zn}^{2+}$ with concentrations of $13.5,13.0,28.1$, and $11.5 \mathrm{mg} / \mathrm{g}$ hydrogel, respectively. The retention capacities were $184.7,175.0,637.6$, and $148.5 \mathrm{mg} / \mathrm{g}$, respectively.

Other studies also proved that different IA hydrogels are useful in metallic ion adsorption [140]. Chitosan is another renewable biopolymer extensively studied for the preparation of natural hydrogels. With the new poly (IA)-grafted crosslinked chitosan nanomaterial-PIACS (Figure 5c) the adsorption capacity was $870.1 \mathrm{mg} / \mathrm{g}$ for $\mathrm{Hg}^{2+}$ and $1320 \mathrm{mg} / \mathrm{g}$ for $\mathrm{Pb}^{2+}$. The $\mathrm{pH}$ of the initial solution, contact time, dosage of adsorbent, and the initial ionic concentration had a strong influence on the high uptake of heavy metal ions. The regeneration of PIACS hydrogel loaded with heavy metals is possible with EDTA, after which it can be continuously used in adsorption-desorption phases [141]. The poly [2-(acrylamido)-2-methyl-1-propanesulfonic acid-co-IA] copolymer separated $\mathrm{Pb}^{2+}, \mathrm{Cu}^{2+}$, and $\mathrm{Cd}^{2+}$ ions in amounts of 1.74, 1.25 and $1.15 \mathrm{mmol} / \mathrm{g}$ polymer, respectively [142]. The inclusion of IA in the co-polymer had a positive effect on the adsorption of $\mathrm{Cu}^{2+}$.

The presence of $\mathrm{Mn}^{2+}$ in surface and groundwater is polluting for the environment and toxic to many living organisms, including humans. The nanomagnetite-charged poly (acrylamide-co-IA) hydrogel presented a competent and cheap $\mathrm{Mn}^{2+}$ elimination method from polluted waters [143]. The efficiency of $\mathrm{Mn}^{2+}$ removal in $60 \mathrm{~min}$ batch method was $>99 \%$ at $25^{\circ} \mathrm{C}$ and $\mathrm{pH}$, and that presents strong results for additional research.

The hydrogels mentioned above had reusable characteristics without any measurable loss in the adsorptive capability throughout the adsorption-desorption cycle. In water or wastewater treatment, there is growing interest in the utilization of hydrogels that offer positive results in the removal of aqueous pollutants. The copolymerization of IA with different natural biopolymers usually improves the hydrogel structure and increases the degree of crosslinking [141,144]. Nevertheless, the essential challenges are in resource recovery, regeneration, reusability, and recovery of hydrogels [145].

\subsubsection{Bio-Based Smart Nanohydrogels for Food Applications}

The creation of food packaging aims to preserve food from oxygen, microorganisms, light, and other environmental conditions. Petroleum-based synthetic polymers presently dominate the packaging industry. Active packaging acts positively on the extension of food preservation and enhances its quality. The primary usage of renewable IA in the food industry is in active packaging like smart nanohydrogels and in the delivery of food preservatives [122,146-148].

Bio-based lactic acid and its copolymers also present a valuable alternative building block in the production of synthetic polymers. Through bulk polycondensation, a copolymer was synthesized from lactic acid, butanediol and IA, poly(D,L-lactic acid-1,4-butanediol-itaconic acid) (Figure 6). Through dispersion on a commercial folding boxboard's backside, the obtained coating was perfectly grease-resistant and exceeded the commercial PLA coatings in performance. This PLA-based polymer (PLABDIA) can be used, especially in packaging dry and greasy goods [149].

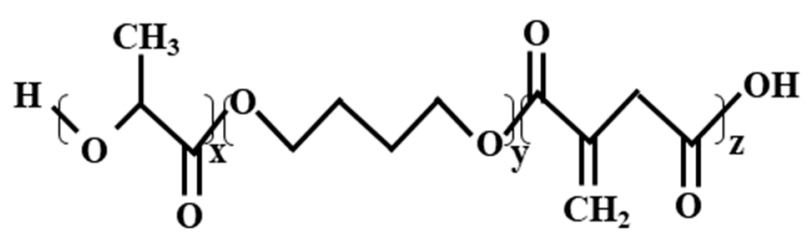

Figure 6. Poly(D,L-lactic acid-1,4-butanediol-itaconic acid) copolymer obtained from polycondensation of D,L-lactic acid, 1,4-butanediol, and IA. 
The use of agricultural wastes as a substitute in the production of natural polymers encourages environmental sustainability. The high quantity of rice husk residues usage as immobilization carrier presents promising future applications. Functionalized rice husk was used recently as a new and inexpensive polymeric carrier for covalently immobilized enzymes (e.g., lipase B from Candida antarctica), and its effectiveness was compared to a classical enzyme carrier (an epoxy methacrylic resin). Lipase $B$ is a broadly used enzyme in the cosmetic, polymer and food sector. When immobilized on rice husk, lipase $B$ proved to be more efficient in solvent-free polycondensation of dimethylitaconate and 1,4-butandiol, than when it is immobilized in the epoxy methacrylic resin [150].

Molecularly imprinted hydrogels production with IA and 2-hydroxyethyl methacrylate present a positive result in biofilm inhibition. IA-based polymers reduced the Pseudomonas aeruginosa biofilm formation by a small amount compared with 2-hydroxyethyl methacrylate-based polymer [151]. Further studies in functional monomer concentration usage and optimizations are required for applying IA on equipment in food processing.

\subsubsection{Nanohydrogel Application in the Pharmaceutical Industry}

Based on the World Health Organization (WHO) reports and according to a systematic analysis published in Lancet, infections are the second leading reason for global fatality [152,153]. This is mostly due to the antibiotic resistance of pathogenic microbes. In the antimicrobial field, hydrogels are useful biopolymers because of their high absorption capacity and delayed/controlled drug release [154]. According to the literature, IA and its derivatives are novel comonomers used in the preparation of a variety of $\mathrm{pH}$-sensitive microgels in anti-tumor drug delivery [155-157]. IA is a remarkably hydrophilic antimicrobial agent, and it is capable of building hydrogen bonds with analogous groups. With the addition of different amounts of IA and crosslinking agents, drug release and drug-loading quantities can be efficiently controlled [131]. Also, due to $\mathrm{pH}$ responsiveness, this comonomer is efficiently used for drug delivery in the gastrointestinal tract [158].

The introduction of IA in polymeric chains improves the $\mathrm{pH}$-sensitive and complexation character of the hydrogel. The enhanced swelling behavior owed to the two carboxylic groups in its structure reacts to electrostatic repulsion at appropriate $\mathrm{pH}$ and medium [159]. IA-based polymeric hydrogels accomplished the best results in inhibiting the Candida albicans fungus. This presents a promising application in vaginal infections, even without any antibiotic. The best swelling capacity, due to carboxylate anion construction obtained at $\mathrm{pH}$ 7.4-10, supports the usage in the biomedical field (neutral $\mathrm{pH}$ body fluid). This hydrogel is also used efficiently in wound treatment to protect against infections. Hydrogels polymerized with IA are nontoxic and $88 \%$ biodegradable under natural processes (when buried in soil for 90 days). With the increase of IA content in the hydrogels, the biodegradation promotion occurs due to an ester group in the IA hydrogel structure. A wide variety of microorganisms like fungi, bacteria, protozoa acted on the hydrogels under aerobic degradation. After degradation, $\mathrm{H}_{2} \mathrm{O}, \mathrm{CH}_{4}, \mathrm{CO}_{2}$ and other compounds were produced [160].

A study with ampicillin and IA grafted tragacanth gum demonstrated that the therapeutic effect was better when ampicillin was loaded in the nanohydrogel. The release rate and the reaction against $E$. coli were more evident: with standard control the inhibition zone was $15 \mathrm{~mm}$, and with the studied nanohydrogels the diameter was $19.3 \mathrm{~mm}$, supporting the usage of these promising nanohydrogels in the administration of different antibiotics [161]. An in vitro study of paracetamol discharge, an exceedingly soluble and permeable drug, also disclosed interesting results through free radical copolymerization of IA and acrylamide. The increase of IA and reduction of the crosslinking agent positively influenced the water and drug uptake of the investigated hydrogels [131].

Cancer is one of the most widespread health burdens. Cancer cells have tenacious characteristics and can quickly adapt to unfavorable environmental conditions. Cancer is frequently treated with chemotherapy [162]. Due to the aggressive side effects and low cellular uptake of chemotherapeutic drugs in cancer cells, a possible solution for this problem is the usage of nano-scale carriers to enhance anticancer therapy. With a $\mathrm{pH}$-responsive multi-drug nanocarrier, the administration of doxorubicin 
(an anticancer drug) and betanin (natural bioactive compound) were facilitated. Cancer cells have lower $\mathrm{pH}$ values than healthy cells; this way, the $\mathrm{pH}$-responsive methoxy poly (ethylene glycol)-poly (2-dimethylamino) ethyl methacrylate-co-itaconic acid PEG-P(DMAEA-co-IAc) nanoparticles support regulated drug discharge at the $\mathrm{pH}$ values of cancer cells (Figure 7a). The use of this nanocarrier, with the simultaneous distribution of betanin and doxorubicin, showed improved cell uptake results, and also the cell apoptosis started [163]. Another bioactive chemo preventer multi-drug carrier system, namely poly (itaconic anhydride-co-3,9-divinyl-2,4,8,10-tetraoxaspiro (5.5) undecane, together with hyaluronic acid P(ITAU)-HA enhanced with quercetin (pro-apoptotic activity on tumor cell lines) and diclofenac (nonsteroidal anti-inflammatory drug) proved to be more reactive to environmental stimuli (Figure $7 \mathrm{~b}$ ). The investigation through in vivo studies of six types of hydrogels with different concentrations of P(ITAU) revealed the best results with $20 \%$ of this matrix. In addition, the swelling degree reliance of the studied "intelligent" gel structures on temperature, $\mathrm{pH}$ and environmental stimuli demonstrated significant features [164].

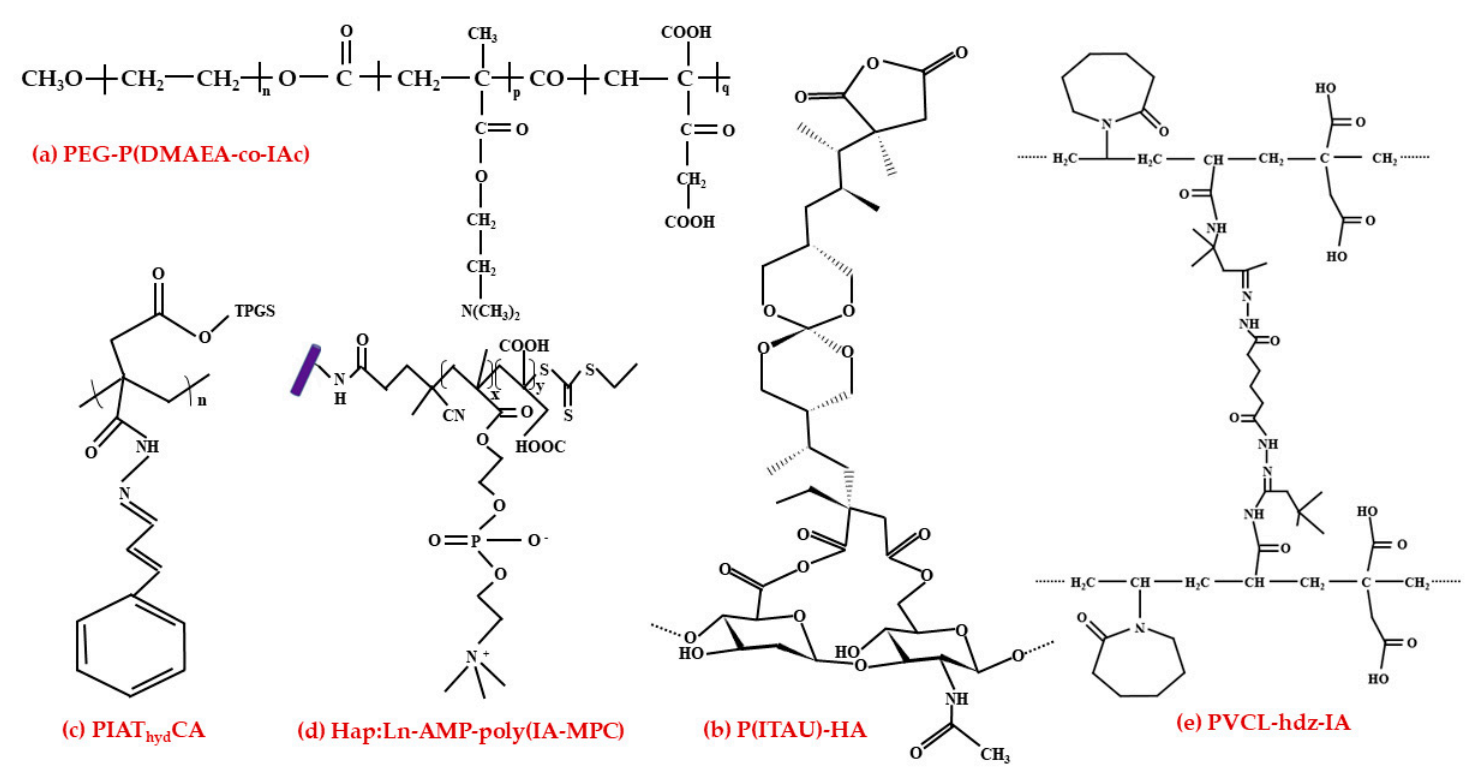

Figure 7. The chemical structure of IA synthesized nano-scale carriers (a) PEG-P(DMAEA-co-IAc), (b) P(ITAU)-HA, (c) PIAThydCA, (d) HAp:Ln-AMP-poly(IA-MPC), (e) PVCL-hdz-IA.

A recent study constructed a system with free radical polymerization of IA to poly (IA) D- $\alpha$-tocopherol polyethylene glycol 1000 succinate and cinnamaldehyde (PIAT ${ }_{\text {hyd }} \mathrm{CA}$ ) through a hydrazone bond (hyd) (Figure 7c).The aim of this study was to increase the intracellular reactive oxygen species level that can eliminate tumor cells (activate apoptosis). Regarding this system, the cinnamaldehyde (sensitive to $\mathrm{pH}$ ) became more bioavailable and, together with the $\mathrm{D}$ - $\alpha$-tocopheryl polyethylene glycol 1000 succinate, activated tumor cell apoptosis. In anticancer treatment, this method is most effectively used due to the mitochondrial apoptosis pathway against MCF-7 breast cancer cells [165]. Owing to their bone-like chemical composition, rare-earth ions doped hydroxyapatite nanoparticles are very efficient in biological imaging. The nanoparticles with adenosine $5^{\prime}$-monophosphate disodium salt and IA polymerized with 2-methacryloyloxyethyl phosphorylcholine-HAp:Ln-AMP-poly(IA-MPC) (Figure 7d) have a usage in cancer treatment by loading the anticancer drug cisplatin. These polymeric composites had unique properties with adequate diffusion in liquids, functional $\mathrm{pH}$ dependency, efficient drug distribution, and adverse toxic effect against A549cells. The composites mentioned above can get through the cell wall and help in drug delivery and the dispersion of active components intracellularly [166]. A two-fold sensitive biodegradable microgel synthesized through precipitation polymerization, namely poly(N-vinyl-caprolactam-co-itaconic acid)_PVCL-hdz-IA (hydrazone-based crosslinking) (Figure 7e), 
is responsive to temperature and pH. PVCL-hdz-IA supplied with doxorubicin discharged the drug favorably at acidic circumstances. With the growth of IA quantity, the volume-phase transition temperature increased. The storing capacity of PVCL-hdz-IA microgel reached $14.1 \%$, acquired through the hydrogen bond interaction and electrostatic energy of doxorubicin and polymer and with exceptional stability at $\mathrm{pH}$ 7.4. The annihilation of human cervical carcinoma cells (HeLa cells) was very powerful with doxorubicin-encapsulated microgel, with a viability of approximately $90 \%$; without the encapsulated drug only $22.6 \%$ were viable [167].

Through the administration of eye-drops, the bioavailability of drugs is very low; to overcome this problem, the production of soft contact lenses may be a good alternative. Eroglu et al. [168] developed minocycline-imprinted hydrogels with distinct functional monomers to treat optical disorders like glaucoma, dry eye, and conjunctivitis. These functional monomers were acrylic acid, methacrylic acid, IA, $1 \mathrm{~N}$ ethylacryl amide, $1 \mathrm{~N}$ isopropyl acrylamide, and hydroxymethyl acrylamide. From the used functional monomers regarding hydrogen bonding with IA, the acquired results were meaningful and indicated their high potential as minocycline imprinted hydrogels. Nevertheless, acrylic acid is a more common monomer used in contact lenses manufacturing; with IA, no further studies were performed. Dosimetry methods need to be accurate and reliable, as it contributes to treatment verification in ionizing radiation. A recent study for radiology usage analyzed the water-equivalence properties of Fricke (cheaper and easier gel dosimeter method) and three different polymer gel dosimeters. Each of the polymer applications in gel dosimeters like IA, N-isopropyl acrylamide, and polyacrylamide presented the same linear trend at a dose-response curve, as well as a raised intensity in water-equivalence [169].

\subsection{Antimicrobial Agent and Medical Applications}

Antibiotic-resistant bacteria causes many bacterial contaminations, which claim a considerable number of lives every year in Europe and the USA ( 50,000 people) [170]. Antimicrobial peptides found in almost every organism's immune system help to react rapidly to pathogens. Based on nature, nowadays there is in progress an ongoing study on synthetic antimicrobial peptides. These polymer coatings need to be long-term stable and easily secured on medical devices [171]. Asymmetrically disubstituted diitaconate monomers copolymerized with dimethyl acrylamide propose an encouraging material against bacterial infections as synthetic mimics of these antimicrobial peptides. The easily polymerized IA is a harmless and ecological source that can also prevent bacterial contamination [172]. The polymers mentioned above are relatively cheap (synthesized by metal-free initiator systems), but further structural optimization is still in progress.

The use of IA salt through the introduction in beverage or food acts as a glycolytic pathway metabolic regulator with antidiabetic, antiobesity, and/or antilipemic consequences. Administration of IA in drinking water to rats revealed diminished weight gain, free fatty acid, blood glucose, and triglyceride levels. These results proved the effectiveness against hyperlipidemia and diabetes in rats. Although IA, along with its salts, was classified as harm-free in these animals with no negative effects, it is still not used in drinks, foods, or medical products [173].

Gestational diabetes mellitus occurs during pregnancy and presents unfavorable severe health effects for mother and child. The screening of disease susceptibility accomplished at the beginning of pregnancy with the detection of biomarkers and some possible metabolic mechanisms demonstrate successful prediction tools. IA was proposed as a novel biomarker because of its presence at a higher concentration in the serum of women at 20 weeks' pregnancy who afterward developed gestational diabetes mellitus compared to controls with uncomplicated pregnancies, which did not develop diabetes [174]. Meiser et al. [175] found that the detection of IA in patients infected with sepsis was impracticable. The analysis of urine and blood samples failed to identify IA at an acceptable concentration in the circulation. As a consequence, this study demonstrated that IA currently has no potential as a biomarker in body fluids (not actively excreted), but its use in immune cells as a pro-inflammatory marker is possible (intracellularly abundant) [175]. 
A study demonstrated that itaconate abolishes visceral fat from glucose in rats through the reduction of fructose 2,6-bisphosphate, which aftermath leads to the restriction of liver glycolysis. IA in rats, due to this phosphofructokinase restriction, may also be associated with metabolism adjustment. IA metabolization rate is slow, which maintains its impact on glycolysis through the lessening of 2,6-bisphosphate quantity [176]. Recent data present that itaconate has a bacteriostatic outcome in macrophage mobilization, such as Mycobacterium tuberculosis or Salmonella enterica. IA is synthesized by the enzyme encoded in the Irg1 gene and is responsible for the macrophage antimicrobial activity [52] and anti-inflammatory effect through Nrf2 activation in mouse and human macrophages [177].

\subsection{Other Applications}

Due to the high concentration of styrene in commercial unsaturated polyester resins, these materials are suspected carcinogens, respiratory tract irritants, and neurotoxins, which can cause severe and prolonged effects on health [178]. To reduce the amount of styrene, bio-based unsaturated polyester resins are synthetized [179].

Nowadays, the high amount of plastic waste is a growing concern. The rise of plastic manufacturing is an ever-increasing global problem, which in 2015 reached approximately 322 million tones and with a quantity twice as large anticipated by 2035. For the reduction of the vast amount of these wastes, the European Commission proposed a strategy for plastics in a circular economy which also included the development of innovative and recycled plastics manufacturing [180].

In this regard, through crosslinking of bio-based unsaturated polyester resins (UPR), and functionalized PET particles (resulted by mechanical size reduction of recycled PET fibers obtained by extrusion) with the addition of a reactive diluent, namely dimethyl itaconate, a new composite material formed. The use of dimethyl itaconate had the purpose of improving the compatibility and interaction between the PET particles and UPR. Petrochemical-based UPRs have better mechanical properties than bio-based UPRs; on the other hand, due to their sustainability, low price, and low carbon footprint, these composites present desirable properties [181]. A research study with diluted dialkyl itaconate involving IA and 1,2-propanediol through melt polycondensation, synthesized effectively $100 \%$ green unsaturated polyester resins [179]. Nevertheless, the growth of the quantity of the itaconate ester group affected the mechanical properties of the polyester resins negatively. Actual bio-based unsaturated polyester resins have the decisive feature of not releasing volatile petrochemical and toxic elements. IA and its derivatives proved to be a low-cost and relatively easy method for the synthesis of these polymers.

\section{Conclusions and Future Perspectives}

Annually, the production of biomass wastes is in the millions of tons range. A possible solution for remediation of these environmental issues can be the biomass utilization in fermentations. Significant potential compounds obtained from bio-wastes are organic acids such as Itaconic Acid (IA), which can also be a substitute for non-renewable petrochemicals, like acrylic acid.

Many types of fungi like $A$. terreus and $U$. maydis can produce IA. Some bacteria like the genetically engineered E. coli and C. glutamicum can also produce significant quantities of IA. IA presents many advantages over fungi, specifically faster growth, easier handling, and accessible gene manipulation. Further research regarding inhibitory components, metabolic regulation and operation conditions to increase the IA yield, is necessary. IA has many novel applications owing to its unique characteristics, namely the structural resemblance to acrylic acid, methacrylic acid and due to an $\alpha, \beta$-unsaturated functionality that allows for the formation of new polyesters. 
Overall, the present manuscript attempts to present the diversity of novel applications of IA as biodegradable hydrogels in water decontamination with unique features efficient in metallic ion adsorption and in smart packaging that can hold food preservatives. In the medical industry, the primary utilization of IA is in controlled drug delivery, especially as multi-drug nanocarrier with great effect on apoptosis of tumor cells. Other medical usages are in wound treatment, optical disorders, in radiology for gel dosimeters and many other applications. Bio-derived polyesters from IA mainly used in elastomer production as a cross-linkable constituent can replace styrene, which has adverse health effects. IA also has an antimicrobial effect.

Lignocellulosic wastes are promising and renewable substrates for IA production, but there is a demand for more studies to make it profitable as an alternative for the traditional methods. Ecological IA-based polymers have abundant application possibilities, and further studies to find other innovative polymers are still required.

Author Contributions: B.-E.T. and D.C.V. wrote and critically reviewed the paper. All authors read and approved the final manuscript.

Funding: This work was supported by the National Research, Development and Innovations Programme for 2015-2020-PNII, developed with the support of UEFISCDI (Project No. PN-III-P1-1.2-PCCDI-2017-0056; 2PCCDI).

Acknowledgments: The authors would like to thank their colleagues from the Department of Food Science, for continued support, and especially to Vasile Coman for critical peer review of the manuscript.

Conflicts of Interest: The authors declare no conflict of interest. The funders had no role in the design of the study; in the collection, analyses, or interpretation of data; in the writing of the manuscript, or in the decision to publish the results.

\section{References}

1. Rodrigues, N.M. Exploring Saccharomyces Cerevisiae to Improve Microbe-Based Production of Itaconic Acid. Master's Thesis, Tecnico Lisboa, Lisboa, Portugal, 2014.

2. Becker, J.; Lange, A.; Fabarius, J.; Wittmann, C. Top value platform chemicals: Bio-based production of organic acids. Curr. Opin. Biotechnol. 2015, 36, 168-175. [CrossRef] [PubMed]

3. Szabo, K.; Cătoi, A.F.; Vodnar, D.C. Bioactive Compounds Extracted from Tomato Processing by-Products as a Source of Valuable Nutrients. Plant Foods Hum. Nutr. 2018, 73, 268-277. [CrossRef] [PubMed]

4. Vodnar, D.C.; Călinoiu, L.F.; Dulf, F.V.; Ştefănescu, B.E.; Crişan, G.; Socaciu, C. Identification of the bioactive compounds and antioxidant, antimutagenic and antimicrobial activities of thermally processed agro-industrial waste. Food Chem. 2017, 231, 131-140. [CrossRef] [PubMed]

5. Isikgor, F.H.; Becer, C.R. Lignocellulosic biomass: A sustainable platform for the production of bio-based chemicals and polymers. Polym. Chem. 2015, 6, 4497-4559. [CrossRef]

6. Sims, R.E.H.; Bassam, N. El Chapter 1 Biomass and Resources. In Bioenergy Options for a Cleaner Environment; Elsevier: Amsterdam, The Netherlands, 2004; pp. 1-28.

7. Lee, S.Y.; Kim, H.U.; Chae, T.U.; Cho, J.S.; Kim, J.W.; Shin, J.H.; Kim, D.I.; Ko, Y.-S.; Jang, W.D.; Jang, Y.-S. A comprehensive metabolic map for production of bio-based chemicals. Nat. Catal. 2019, 2, 18-33. [CrossRef]

8. Popović, I.; Katsikas, L. The thermal degradation of some polymeric di-alkyl esters of itaconic acid. J. Serbian Chem. Soc. 2013, 78, 2179-2200. [CrossRef]

9. Ishii-Hyakutake, M.; Mizuno, S.; Tsuge, T. Biosynthesis and Characteristics of Aromatic Polyhydroxyalkanoates. Polymers (Basel) 2018, 10, 1267. [CrossRef]

10. Sun, J.; Shen, J.; Chen, S.; Cooper, M.A.; Fu, H.; Wu, D.; Yang, Z. Nanofiller reinforced biodegradable PLA/PHA composites: Current status and future trends. Polymers (Basel) 2018, 10, 505. [CrossRef]

11. Weastra S.r.o. WP 8.1. Determination of Market Potential for Selected Platform Chemicals Market Study on Succinic Acid, Itaconic Acid and 2,5-Furandicarboxylic Acid; Weastra s.r.o.: Bratislava, Slovakia, 2011.

12. De Carvalho, J.C.; Magalhaes, A.I.; Soccol, C.R. (PDF) Biobased itaconic acid market and research trends-Is it really a promising chemical? Chim. Oggi-Chem. Today 2018, 36, 56-58.

13. Mondala, A.H. Direct fungal fermentation of lignocellulosic biomass into itaconic, fumaric, and malic acids: Current and future prospects. J. Ind. Microbiol. Biotechnol. 2015, 42, 487-506. [CrossRef] 
14. Robert, T.; Friebel, S. Itaconic acid-a versatile building block for renewable polyesters with enhanced functionality. Green Chem. 2016, 18, 2922-2934. [CrossRef]

15. Yang, W.; Hu, Y.; Chen, Z.; Jiang, X.; Wang, J.; Wang, R. Solubility of itaconic acid in different organic solvents: Experimental measurement and thermodynamic modeling. Fluid Phase Equilib. 2012, 314, 180-184. [CrossRef]

16. Fawcett, H.H. Kirk-Othmer concise encyclopedia of chemical technology. J. Hazard. Mater. 1985, $24-25$. [CrossRef]

17. Raghu, C.; Raghuveer, P. Itaconic acid Production-A short review. Int. J. Adv. Eng. Technol. Manag. Appl. Sci. 2017, 4, 8-15.

18. Willke, T.; Vorlop, K.D. Biotechnological production of itaconic acid. Appl. Microbiol. Biotechnol. 2001, 56, 289-295. [CrossRef] [PubMed]

19. Larsen, H.; Eimhjellen, K.E.K. The mechanism of itaconic acid formation by Aspergillus terreus. 1. The effect of acidity. Biochem. J. 1955, 6217, 135-139. [CrossRef] [PubMed]

20. Baup, S. Ueber eine neue Pyrogen-Citronensäure, und über Benennung der Pyrogen-Säuren überhaupt. Ann. Chim. Phys. 1837, 39-41. [CrossRef]

21. Kinoshita, K. Über die Produktion von Itaconsäure und Mannit durch einen neuen Schimmelpilz, Aspergillus itaconicus. Acta Phytochim. 1932, 5, 271-287.

22. Nelson, G.E.N.; Traufler, D.H.; Kelley, S.E.; Lockwood, L.B. Production of Itaconic Acid by Aspergillus terreus in 20-Liter Fermentors. Ind. Eng. Chem. 2005, 44, 1166-1168. [CrossRef]

23. Eimhjellen, K.E.; Larsen, H. The mechanism of itaconic acid formation by Aspergillus terreus. 2. The effect of substrates and inhibitors. Biochem. J. 1955, 60, 139-147. [CrossRef]

24. Da Cruz, J.C.; Camporese Sérvulo, E.F.; de Castro, A.M. Microbial Production of Itaconic Acid. In Microbial Production of Food Ingredients and Additives; Elsevier: Amsterdam, The Netherlands, 2017; pp. 291-316, ISBN 9780128115206.

25. Hegde, K.; Prabhu, A.; Sarma, S.J.; Brar, S.K.; Venkata Dasu, V. Potential Applications of Renewable Itaconic Acid for the Synthesis of 3-Methyltetrahydrofuran; Elsevier Inc.: Amsterdam, The Netherlands, 2016; ISBN 9780128029800.

26. Tate, B.E. Polymerization of itaconic acid and derivatives BT-Fortschritte der Hochpolymeren-Forschung. Adv. Polym. Sci. 1967, 5, 214-232.

27. Bafana, R.; Pandey, R.A. New approaches for itaconic acid production: Bottlenecks and possible remedies. Crit. Rev. Biotechnol. 2017, 38, 68-82. [CrossRef] [PubMed]

28. Magalhães, A.I.; de Carvalho, J.C.; Thoms, J.F.; Medina, J.D.C.; Soccol, C.R. Techno-economic analysis of downstream processes in itaconic acid production from fermentation broth. J. Clean. Prod. 2019, 206, 336-348. [CrossRef]

29. Boruta, T.; Bizukojc, M. Production of lovastatin and itaconic acid by Aspergillus terreus: A comparative perspective. World J. Microbiol. Biotechnol. 2017, 33, 1-12. [CrossRef] [PubMed]

30. Saha, B.C. Emerging biotechnologies for production of itaconic acid and its applications as a platform chemical. J. Ind. Microbiol. Biotechnol. 2017, 44, 303-315. [CrossRef] [PubMed]

31. Zhao, M.; Lu, X.; Zong, H.; Li, J.; Zhuge, B. Itaconic acid production in micro-organisms. Biotechnol. Lett. 2018. [CrossRef]

32. Yamamoto, K.; Nagata, K.; Ohara, H.; Aso, Y. Challenges in the production of itaconic acid by metabolically. Bioengineered 2015, 6, 303-306. [CrossRef]

33. Cunha da Cruz, J.; Machado de Castro, A.; Camporese Sérvulo, E.F. World market and biotechnological production of itaconic acid. 3 Biotech 2018, 8, 138. [CrossRef]

34. Kumar, S.; Krishnan, S.; Samal, S.K.; Mohanty, S.; Nayak, S.K. Itaconic acid used as a versatile building block for the synthesis of renewable resource based Resins and Polyesters for Future Prospective: A Review. Polym. Int. 2017, 66, 1349-1363. [CrossRef]

35. Werpy, T.; Petersen, G. Top Value Added Chemicals from Biomass Volume I-Results of Screening for Potential Candidates from Sugars and Synthesis Gas Top Value Added Chemicals From Biomass Volume I: Results of Screening for Potential Candidates; U.S. Department of Energy, Energy Efficiency and Renewable Energy: Washington, DC, USA, 2004; Volume I.

36. Klement, T.; Büchs, J. Itaconic acid-A biotechnological process in change. Bioresour. Technol. 2013, 135, 422-431. [CrossRef] 
37. Okabe, M.; Lies, D.; Kanamasa, S.; Park, E.Y. Biotechnological production of itaconic acid and its biosynthesis in Aspergillus terreus. Appl. Microbiol. Biotechnol. 2009, 84, 597-606. [CrossRef] [PubMed]

38. Global Industry Analysts. The Global Itaconic Acid Market-Trends, Drivers \& Projections. 2016. Available online: https://www.strategyr.com/MarketResearch/Itaconic_Acid_IA_Market_Trends.asp (accessed on 19 April 2019).

39. Sudip, S. Itaconic acid Market Is Expected to Reach USD 204.6 Million by 2023. Available online: http: //www.transparencymarketresearch.com/pressrelease/itaconic-acid-market.htm (accessed on 21 January 2019).

40. Karaffa, L.; Kubicek, C.P. Citric acid and itaconic acid accumulation: Variations of the same story? Appl. Microbiol. Biotechnol. 2019, 103, 2889-2902. [CrossRef] [PubMed]

41. Bozell, J.J.; Petersen, G.R. Technology development for the production of biobased products from biorefinery carbohydrates-The US Department of Energy's “Top 10" revisited. Green Chem. 2010, 12, 539-554. [CrossRef]

42. Van der Straat, L.; Vernooij, M.; Lammers, M.; van den Berg, W.; Schonewille, T.; Cordewener, J.; van der Meer, I.; Koops, A.; De Graaff, L.H. Expression of the Aspergillus terreus itaconic acid biosynthesis cluster in Aspergillus niger. Microb. Cell Fact. 2014, 13, 11. [CrossRef] [PubMed]

43. Hossain, A.H.; Li, A.; Brickwedde, A.; Wilms, L.; Caspers, M.; Overkamp, K.; Punt, P.J. Rewiring a secondary metabolite pathway towards itaconic acid production in Aspergillus niger. Microb. Cell Fact. 2016, 15, 130. [CrossRef] [PubMed]

44. Molnár, Á.P.; Németh, Z.; Kolláth, I.S.; Fekete, E.; Flipphi, M.; Ág, N.; Soós, Á.; Kovács, B.; Sándor, E.; Kubicek, C.P.; et al. High oxygen tension increases itaconic acid accumulation, glucose consumption, and the expression and activity of alternative oxidase in Aspergillus terreus. Appl. Microbiol. Biotechnol. 2018, 102, 8799-8808. [CrossRef]

45. Krull, S.; Eidt, L.; Hevekerl, A.; Kuenz, A.; Prüße, U. Itaconic acid production from wheat chaff by Aspergillus terreus. Process Biochem. 2017, 63, 169-176. [CrossRef]

46. Carstensen, F.; Klement, T.; Büchs, J.; Melin, T.; Wessling, M. Continuous production and recovery of itaconic acid in a membrane bioreactor. Bioresour. Technol. 2013, 137, 179-187. [CrossRef]

47. Geiser, E.; Przybilla, S.K.; Buckel, W.; Wierckx, N.; Lars, M.; Bölker, M. Ustilago maydis produces itaconic acid via the unusual intermediate trans -aconitate. Microb. Biotechnol. 2016, 9, 116-126. Available online: https://www.ncbi.nlm.nih.gov/pmc/articles/PMC4720413/ (accessed on 24 January 2019). [CrossRef]

48. Levinson, W.E.; Kurtzman, C.P.; Kuo, T.M. Production of itaconic acid by Pseudozyma antarctica NRRL Y-7808 under nitrogen-limited growth conditions. Enzyme Microb. Technol. 2006, 39, 824-827. [CrossRef]

49. Blazeck, J.; Hill, A.; Jamoussi, M.; Pan, A.; Miller, J.; Alper, H.S. Metabolic engineering of Yarrowia lipolytica for itaconic acid production. Metab. Eng. 2015, 32, 66-73. [CrossRef] [PubMed]

50. Chen, M.; Huang, X.; Zhong, C.; Li, J.; Lu, X. Identification of an itaconic acid degrading pathway in itaconic acid producing Aspergillus terreus. Appl. Microbiol. Biotechnol. 2016, 100, 7541-7548. [CrossRef]

51. Li, A.; van Luijk, N.; ter Beek, M.; Caspers, M.; Punt, P.; van der Werf, M. A clone-based transcriptomics approach for the identification of genes relevant for itaconic acid production in Aspergillus. Fungal Genet. Biol. 2011, 48, 602-611. [CrossRef] [PubMed]

52. Michelucci, A.; Cordes, T.; Ghelfi, J.; Pailot, A.; Reiling, N.; Goldmann, O.; Binz, T.; Wegner, A.; Tallam, A.; Rausell, A.; et al. Immune-responsive gene 1 protein links metabolism to immunity by catalyzing itaconic acid production. Proc. Natl. Acad. Sci. USA 2013, 110, 7820-7825. [CrossRef] [PubMed]

53. Diskin, C.; Pålsson-McDermott, E.M. Metabolic modulation in macrophage effector function. Front. Immunol. 2018, 9, 270. [CrossRef] [PubMed]

54. Jha, A.K.; Huang, S.C.C.; Sergushichev, A.; Lampropoulou, V.; Ivanova, Y.; Loginicheva, E.; Chmielewski, K.; Stewart, K.M.; Ashall, J.; Everts, B.; et al. Network integration of parallel metabolic and transcriptional data reveals metabolic modules that regulate macrophage polarization. Immunity 2015, 42, 419-430. [CrossRef] [PubMed]

55. Strelko, C.L.; Lu, W.; Dufort, F.J.; Seyfried, T.N.; Chiles, T.C.; Rabinowitz, J.D.; Roberts, M.F. Itaconic acid is a mammalian metabolite induced during macrophage activation. J. Am. Chem. Soc. 2011, 133, 16386-16389. [CrossRef]

56. Park, H.S.; Jun, S.C.; Han, K.H.; Hong, S.B.; Yu, J.H. Diversity, Application, and Synthetic Biology of Industrially Important Aspergillus Fungi. Adv. Appl. Microbiol. 2017, 100, 161-202. [PubMed]

57. Slade, R.; Bauen, A.; Gross, R. Global bioenergy resources. Nat. Clim. Chang. 2014, 4, 99-105. [CrossRef] 
58. Ben, H.; Wu, Z.; Han, G.; Jiang, W.; Ragauskas, A. Pyrolytic behavior of major biomass components in waste biomass. Polymers (Basel) 2019, 11, 324. [CrossRef]

59. Van Meerbeek, K.; Muys, B.; Hermy, M. Lignocellulosic biomass for bioenergy beyond intensive cropland and forests. Renew. Sustain. Energy Rev. 2019, 102, 139-149. [CrossRef]

60. Regestein, L.; Klement, T.; Grande, P.; Kreyenschulte, D.; Heyman, B.; Maßmann, T.; Eggert, A.; Sengpiel, R.; Wang, Y.; Wierckx, N.; et al. From beech wood to itaconic acid: Case study on biorefinery process integration. Biotechnol. Biofuels 2018, 11, 279. [CrossRef] [PubMed]

61. Bafana, R.; Sivanesan, S.; Pandey, R.A. Itaconic Acid Production by Filamentous Fungi in Starch-Rich Industrial Residues. Indian J. Microbiol. 2017, 57, 322-328. [CrossRef] [PubMed]

62. Huang, X.; Chen, M.; Lu, X.; Li, Y.; Li, X.; Li, J.J. Direct production of itaconic acid from liquefied corn starch by genetically engineered Aspergillus terreus. Microb. Cell Fact. 2014, 13, 108. [CrossRef] [PubMed]

63. Pedroso, G.B.; Montipó, S.; Mario, D.A.N.; Alves, S.H.; Martins, A.F. Building block itaconic acid from left-over biomass. Biomass Convers. Biorefinery 2017, 7, 23-35. [CrossRef]

64. Wu, X.; Liu, Q.; Deng, Y.; Li, J.; Chen, X.; Gu, Y.; Lv, X.; Zheng, Z.; Jiang, S.; Li, X. Production of itaconic acid by biotransformation of wheat bran hydrolysate with Aspergillus terreus CICC40205 mutant. Bioresour. Technol. 2017, 241, 25-34. [CrossRef]

65. Madadi, M.; Tu, Y.; Abbas, A. Recent Status on Enzymatic Saccharification of Lignocellulosic Biomass for Bioethanol Production Recent Status on Enzymatic Saccharification of Lignocellulosic Biomass for Bioethanol Production. Eletronic J. Biol. 2017, 13, 135-143.

66. Kuenz, A.; Gallenmüller, Y.; Willke, T.; Vorlop, K.D. Microbial production of itaconic acid: Developing a stable platform for high product concentrations. Appl. Microbiol. Biotechnol. 2012, 96, 1209-1216. [CrossRef]

67. Saha, B.C.; Kennedy, G.J. Mannose and galactose as substrates for production of itaconic acid by Aspergillus terreus. Lett. Appl. Microbiol. 2017, 65, 527-533. [CrossRef] [PubMed]

68. Hevekerl, A.; Kuenz, A.; Vorlop, K.-D. Influence of the $\mathrm{pH}$ on the itaconic acid production with Aspergillus terreus. Appl. Microbiol. Biotechnol. 2014, 98, 10005-10012. [CrossRef] [PubMed]

69. Kuenz, A.; Krull, S. Biotechnological production of itaconic acid-Things you have to know. Appl. Microbiol. Biotechnol. 2018, 102, 3901-3914. [CrossRef]

70. Huang, X.; Lu, X.; Li, Y.; Li, X.; Li, J.J. Improving itaconic acid production through genetic engineering of an industrial Aspergillus terreus strain. Microb. Cell Fact. 2014, 13, 119. [CrossRef] [PubMed]

71. Horitsu, H.; Takahashi, Y.; Tsuda, J.; Kawai, K.; Kawano, Y. Production of itaconic acid by Aspergillus terreus immobilized in polyacrylamide gels. Eur. J. Appl. Microbiol. Biotechnol. 1983, 18, 358-360. [CrossRef]

72. Yahiro, K.; Shibata, S.; Jia, S.; Park, Y. Efficient Itaconic Acid Production from Raw Corn Starch. J. Ferment. Bioeng. 1997, 84, 375-377. [CrossRef]

73. Rao, D.M.; Hussain, S.M.D.J.; Rangadu, V.P.; Subramanyam, K.; Krishna, G.S.; Swamy, A.V.N. Fermentatative production of itaconic acid by Aspergillus terreus using Jatropha seed cake. Afr. J. Biotechnol. 2007, 6, 2140-2142.

74. Yoshinoubu, K.; Aki, K.; Eisuke, F. USE of Itaconic Acid for Regulation of Glycolytic Metabolism-Suntory Limited. Europe Patent EP1062954A1, 27 December 2000.

75. Krull, S.; Hevekerl, A.; Kuenz, A.; Prüße, U. Process development of itaconic acid production by a natural wild type strain of Aspergillus terreus to reach industrially relevant final titers. Appl. Microbiol. Biotechnol. 2017, 101, 4063-4072. [CrossRef] [PubMed]

76. Kreyenschulte, D.; Heyman, B.; Eggert, A.; Maßmann, T.; Kalvelage, C.; Kossack, R.; Regestein, L.; Jupke, A.; Büchs, J. In situ reactive extraction of itaconic acid during fermentation of Aspergillus terreus. Biochem. Eng. J. 2018, 135, 133-141. [CrossRef]

77. Saha, B.C.; Kennedy, G.J. Ninety six well microtiter plate as microbioreactors for production of itaconic acid by six Aspergillus terreus strains. J. Microbiol. Methods 2018, 144, 53-59. [CrossRef]

78. Reddy, C.S.K.; Singh, R.P. Enhanced production of itaconic acid from corn starch and market refuse fruits by genetically manipulated Aspergillus terreus SKR10. Bioresour. Technol. 2002, 85, 69-71. [CrossRef]

79. Klement, T.; Milker, S.; Jäger, G.; Grande, P.M.; De María, P.D.; Büchs, J. Biomass pretreatment affects Ustilago maydis in producing itaconic acid. Microb. Cell Fact. 2012, 11, 43. [CrossRef] [PubMed] 
80. Tabuchi, T.; Sugisawa, T.; Ishidori, T.; Nakahara, T.; Sugiyama, J. Itaconic acid fermentation by a yeast belonging to the genus candida. Agric. Biol. Chem. 1981, 45, 475-479. [CrossRef]

81. Otten, A.; Brocker, M.; Bott, M. Metabolic engineering of Corynebacterium glutamicum for the production of itaconate. Metab. Eng. 2015, 30, 156-165. [CrossRef] [PubMed]

82. Zambanini, T.; Hosseinpour Tehrani, H.; Geiser, E.; Merker, D.; Schleese, S.; Krabbe, J.; Buescher, J.M.; Meurer, G.; Wierckx, N.; Blank, L.M. Efficient itaconic acid production from glycerol with Ustilago vetiveriae TZ1. Biotechnol. Biofuels 2017, 10, 131. [CrossRef] [PubMed]

83. Geiser, E.; Reindl, M.; Blank, L.M.; Feldbrügge, M.; Wierckx, N.; Schipper, K. Activating Intrinsic Carbohydrate-Active Enzymes of the Smut Fungus Ustilago maydis for the Degradation of Plant Cell Wall Components. Appl. Environ. Microbiol. 2016, 82, 5174-5185. [CrossRef]

84. Harder, B.-J.; Bettenbrock, K.; Klamt, S. Model-based metabolic engineering enables high yield itaconic acid production by Escherichia coli. Metab. Eng. 2016, 38, 29-37. [CrossRef]

85. Okamoto, S.; Chin, T.; Nagata, K.; Takahashi, T.; Ohara, H.; Aso, Y. Production of itaconic acid in Escherichia coli expressing recombinant $\alpha$-amylase using starch as substrate. J. Biosci. Bioeng. 2015, 119, 548-553. [CrossRef]

86. Li, A.; Pfelzer, N.; Zuijderwijk, R.; Punt, P. Enhanced itaconic acid production in Aspergillus niger using genetic modification and medium optimization. BMC Biotechnol. 2012, 12, 57. [CrossRef]

87. Van Der Straat, L.; Tamayo-ramos, J.A.; Schonewille, T.; Graaff, L.H. De Overexpression of a modified 6-phosphofructo-1-kinase results in an increased itaconic acid productivity in Aspergillus niger. AMB Express 2013, 3, 1. [CrossRef]

88. Yin, X.; Shin, H.; Li, J.; Du, G.; Liu, L.; Chen, J. Pgas, a Low-pH-Induced Promoter, as a Tool for Dynamic Control of Gene Expression for Metabolic Engineering of Aspergillus niger. Appl. Environ. Microbiol. 2017, 83. [CrossRef]

89. Mitrea, L.; Trif, M.; Cătoi, A.F.; Vodnar, D.C. Utilization of biodiesel derived-glycerol for 1,3-PD and citric acid production. Microb. Cell Fact. 2017, 16, 190. [CrossRef]

90. Mitrea, L.; Călinoiu, L.-F.; Precup, G.; Bindea, M.; Rusu, B.; Trif, M.; Ştefănescu, B.-E.; Pop, I.-D.; Vodnar, D.-C. Isolated Microorganisms for Bioconversion of Biodiesel-Derived Glycerol Into 1,3-Propanediol. Bull. UASVM Food Sci. Technol. 2017, 74, 43-49. [CrossRef]

91. Dulf, E.H.; Vodnar, D.C.; Dulf, F.V. Modeling tool using neural networks for 1 (+)- lactic acid production by pellet-Form Rhizopus oryzae NRRL 395 on biodiesel crude glycerol. Chem. Cent. J. 2018, 12, 124. [CrossRef] [PubMed]

92. Bindea, M.; Rusu, B.; Rusu, A.; Trif, M.; Leopold, L.F.; Dulf, F.; Vodnar, D.C. Valorification of crude glycerol for pure fractions of docosahexaenoic acid and $\beta$-carotene production by using Schizochytrium limacinum and Blakeslea trispora. Microb. Cell Fact. 2018, 17, 97. [CrossRef] [PubMed]

93. Shi, S.; Zhao, H. Metabolic Engineering of Oleaginous Yeasts for Production of Fuels and Chemicals. Front. Microbiol. 2017, 8, 2185. [CrossRef] [PubMed]

94. Vuoristo, K.S.; Mars, A.E.; Sangra, J.V.; Springer, J.; Eggink, G.; Sanders, J.P.M. Metabolic engineering of the mixed-acid fermentation pathway of Escherichia coli for anaerobic production of glutamate and itaconate. $A M B$ Express 2015, 5, 61. [CrossRef] [PubMed]

95. Rau, M.H.; Calero, P.; Lennen, R.M.; Long, K.S.; Nielsen, A.T. Genome-wide Escherichia coli stress response and improved tolerance towards industrially relevant chemicals. Microb. Cell Fact. 2016, 15, 176. [CrossRef] [PubMed]

96. Kim, J.; Seo, H.; Bhatia, S.K.; Song, H.; Kim, J.; Jeon, J.; Choi, K.; Kim, W.; Yoon, J.; Kim, Y. Production of itaconate by whole-cell bioconversion of citrate mediated by expression of multiple genes in Escherichia coli. Nat. Publ. Gr. 2017, 7, 39786.

97. Chang, P.; Chen, G.S.; Chu, H.Y.; Lu, K.W.; Shen, C.R. Engineering efficient production of itaconic acid from diverse substrates in Escherichia coli. J. Biotechnol. 2017, 249, 73-81. [CrossRef]

98. Moon, Y.-M.; Gurav, R.; Kim, J.; Hong, Y.-G.; Bhatia, S.K.; Jung, H.-R.; Hong, J.-W.; Choi, T.R.; Yang, S.Y.; Park, H.Y.; et al. Whole-cell Immobilization of Engineered Escherichia coli JY001 with Barium-alginate for Itaconic Acid Production. Biotechnol. Bioprocess Eng. 2018, 23, 442-447. [CrossRef] 
99. Li, A.; Pfelzer, N.; Zuijderwijk, R.; Brickwedde, A.; Van Zeijl, C.; Punt, P. Reduced by-product formation and modified oxygen availability improve itaconic acid production in Aspergillus niger. Appl. Microbiol. Biotechnol. 2013, 97, 3901-3911. [CrossRef]

100. Steiger, M.G.; Blumhoff, M.L.; Mattanovich, D.; Sauer, M. Biochemistry of microbial itaconic acid production. Front. Microbiol. 2013, 4, 23. [CrossRef] [PubMed]

101. Agbor, V.; Carere, C.; Cicek, N.; Sparling, R.; Levin, D. Biomass pretreatment for consolidated bioprocessing (CBP). In Advances in Biorefineries: Biomass and Waste Supply Chain Exploitation; Elsevier: Amsterdam, The Netherlands, 2014; pp. 234-258, ISBN 9780857095213.

102. Den Haan, R.; van Rensburg, E.; Rose, S.H.; Görgens, J.F.; van Zyl, W.H. Progress and challenges in the engineering of non-cellulolytic microorganisms for consolidated bioprocessing. Curr. Opin. Biotechnol. 2015, 33, 15-22. [CrossRef] [PubMed]

103. Antonov, E.; Schlembach, I.; Regestein, L.; Rosenbaum, M.A.; Büchs, J. Process relevant screening of cellulolytic organisms for consolidated bioprocessing. Biotechnol. Biofuels 2017, 10, 106. [CrossRef] [PubMed]

104. Geiser, E.; Wiebach, V.; Wierckx, N.; Blank, L.M. Prospecting the biodiversity of the fungal family Ustilaginaceae for the production of value-added chemicals. Fungal Biol. Biotechnol. 2014, 1, 2. [CrossRef] [PubMed]

105. Guevarra, E.D.; Tabuchi, T. Accumulation of itaconic, 2-hydroxyparaconic, itatartaric, and malic acids by strains of the genus ustilago. Agric. Biol. Chem. 1990, 54, 2353-2358. [CrossRef]

106. Zambanini, T.; Kleineberg, W.; Sarikaya, E.; Buescher, J.M.; Meurer, G.; Wierckx, N.; Blank, L.M. Enhanced malic acid production from glycerol with high-cell density Ustilago trichophora TZ1 cultivations. Biotechnol. Biofuels 2016, 9, 135. [CrossRef] [PubMed]

107. Schute, K.; Detoni, C.; Kann, A.; Jung, O.; Palkovits, R.; Rose, M. Separation in biorefineries by liquid phase adsorption: Itaconic acid as case study. ACS Sustain. Chem. Eng. 2016, 4, 5921-5928. [CrossRef]

108. Magalhães, A.I.; de Carvalho, J.C.; Medina, J.D.C.; Soccol, C.R. Downstream process development in biotechnological itaconic acid manufacturing. Appl. Microbiol. Biotechnol. 2017, 101, 1-12. [CrossRef] [PubMed]

109. Dwiarti, L.; Otsuka, M.; Miura, S.; Yaguchi, M.; Okabe, M. Itaconic acid production using sago starch hydrolysate by Aspergillus terreus TN484-M1. Bioresour. Technol. 2007, 98, 3329-3337. [CrossRef] [PubMed]

110. Urbanus, J.; Roelands, C.P.M.; Verdoes, D.; ter Horst, J.H. Intensified crystallization in complex media: Heuristics for crystallization of platform chemicals. Chem. Eng. Sci. 2012, 77, 18-25. [CrossRef]

111. Eggert, A.; Maßmann, T.; Kreyenschulte, D.; Becker, M.; Heyman, B.; Büchs, J.; Jupke, A. Integrated in-situ product removal process concept for itaconic acid by reactive extraction, $\mathrm{pH}$-shift back extraction and purification by $\mathrm{pH}$-shift crystallization. Sep. Purif. Technol. 2019, 463-472. [CrossRef]

112. Raghuwanshi, S.S.; Rathore, A.K.; Pal, S. Recovery of Itaconic Acid From An Aqueous Solution By Using Chemically Modified Vegetable Oil As Diluent. Res. J. Pharm. Biol. Chem. Sci. 2018, 9, 81-86.

113. Kaur, G.; Maesen, M.; Garcia-Gonzalez, L.; De Wever, H.; Elst, K. Novel Intensified Back Extraction Process for Itaconic Acid: Toward in Situ Product Recovery for Itaconic Acid Fermentation. ACS Sustain. Chem. Eng. 2018, 6, 7403-7411. [CrossRef]

114. Gorden, J.; Geiser, E.; Wierckx, N.; Blank, L.M.; Zeiner, T.; Brandenbusch, C. Integrated process development of a reactive extraction concept for itaconic acid and application to a real fermentation broth. Eng. Life Sci. 2017, 17, 809-816. [CrossRef]

115. Varga, V.; Bélafi-Bakó, K.; Vozik, D.; Nemestóthy, N. Recovery of Itaconic Acid by Electrodialysis. Hungarian J. Ind. Chem. 2019, 46, 43-46. [CrossRef]

116. Qi, P.; Chen, H.L.; Nguyen, H.T.H.; Lin, C.C.; Miller, S.A. Synthesis of biorenewable and water-degradable polylactam esters from itaconic acid. Green Chem. 2016, 18, 4170-4175. [CrossRef]

117. Lei, W.; Yang, X.; Qiao, H.; Shi, D.; Wang, R.; Zhang, L. Renewable resource-based elastomer nanocomposite derived from myrcene, ethanol, itaconic acid and nanosilica: Design, preparation and properties. Eur. Polym. J. 2018, 106, 1-8. [CrossRef]

118. Louven, Y.; Schute, K.; Palkovits, R. Ruthenium Catalyzed Reductive Transformation of Itaconic Acid and Ammonia Into 3- and 4-Methyl-pyrrolidone. ChemCatChem 2019, 11, 439-442. [CrossRef]

119. Park, D.S.; Abdelrahman, O.A.; Vinter, K.P.; Howe, P.M.; Bond, J.Q.; Reineke, T.M.; Zhang, K.; Dauenhauer, P.J. Multifunctional Cascade Catalysis of Itaconic Acid Hydrodeoxygenation to 3-Methyl-tetrahydrofuran. ACS Sustain. Chem. Eng. 2018, 6, 9394-9402. [CrossRef] 
120. Kassi, E.; Loizou, E.; Porcar, L.; Patrickios, C.S. Di(n-butyl) itaconate end-functionalized polymers: Synthesis by group transfer polymerization and solution characterization. Eur. Polym. J. 2011, 47, 816-822. [CrossRef]

121. Gumare, N. Global Industry Analysis, Size, Share, Growth, Trends, and Forecast 2015-2023 Report. Itaconic Acid Market for Synthetic Latex, Unsaturated Polyester Resins, Detergents, Superabsorbent Polymers (SAP), and Other Applications; U.S.A. 2015. Available online: https://www.transparencymarketresearch.com/ itaconic-acid-market.html (accessed on 15 March 2019).

122. Fuciños, C.; Fuciños, P.; Amado, I.R.; Míguez, M.; Fajardo, P.; Pastrana, L.M.; Rúa, M.L. Smart Nanohydrogels for Controlled Release of Food Preservatives; Elsevier Inc.: Amsterdam, The Netherlands, 2016; ISBN 9780128007235.

123. Tomić, S.L.; Suljovrujić, E.H.; Filipović, J.M. Biocompatible and bioadhesive hydrogels based on 2-hydroxyethyl methacrylate, monofunctional poly(alkylene glycol)s and itaconic acid. Polym. Bull. 2006, 57, 691-702. [CrossRef]

124. Ahmed, E.M. Hydrogel: Preparation, characterization, and applications: A review. J. Adv. Res. 2015, 6, 105-121. [CrossRef] [PubMed]

125. Bahram, M.; Mohseni, N.; Moghtader, M. An Introduction to Hydrogels and Some Recent Applications. In Emerging Concepts in Analysis and Applications of Hydrogels Chemical; Majee, S.B., Ed.; Intech: Rijeka, Croatia, 2016; pp. 10-38, ISBN 978-953-51-2510-5.

126. Athukoralalage, S.S.; Rajkamal, B.; Naba, D.K.; Choudhury, N.R. 3D Bioprinted Nanocellulose-Based Hydrogels for Tissue Engineering Applications: A Brief Review. Polymers 2019, 11, 898. [CrossRef] [PubMed]

127. Dannert, C.; Stokke, B.T.; Dias, R.S. Nanoparticle-Hydrogel Composites: From Molecular Interactions to Macroscopic Behavior. Polymers (Basel) 2019, 11, 275. [CrossRef] [PubMed]

128. Elsayed, M.M. Hydrogel Preparation Technologies: Relevance Kinetics, Thermodynamics and Scaling up Aspects. J. Polym. Environ. 2019, 27, 871-891. [CrossRef]

129. Harrison, I.P.; Spada, F. Hydrogels for atopic dermatitis and wound management: A superior drug delivery vehicle. Pharmaceutics 2018, 10, 71. [CrossRef] [PubMed]

130. Chirani, N.; Yahia, L.; Gritsch, L.; Motta, F.L.; Chirani, S.; Faré, S. History and Applications of Hydrogels. J. Biomed. Sci. 2015, 4, 2.

131. Stanojević, M.; Krušić, M.K.; Filipović, J.; Parojčić, J.; Stupar, M. An investigation into the influence of hydrogel composition on swelling behavior and drug release from poly(acrylamide-co-itaconic acid) hydrogels in various media. Drug Deliv. J. Deliv. Target. Ther. Agents 2006, 13, 1-7. [CrossRef]

132. El-Halah, A.; Machado, D.; González, N.; Contreras, J.; López-Carrasquero, F. Use of super absorbent hydrogels derivative from acrylamide with itaconic acid and itaconates to remove metal ions from aqueous solutions. J. Appl. Polym. Sci. 2019, 136, 46999. [CrossRef]

133. Amonpattaratkit, P.; Khunmanee, S.; Kim, D.H.; Park, H. Synthesis and Characterization of Gelatin-Based Crosslinkers for the Fabrication of Superabsorbent Hydrogels. Materials (Basel) 2017, 10, 826. [CrossRef]

134. Mohammadzadeh Pakdel, P.; Peighambardoust, S.J. A review on acrylic based hydrogels and their applications in wastewater treatment. J. Environ. Manag. 2018, 217, 123-143. [CrossRef] [PubMed]

135. Foungfung, D.; Phattanarudee, S.; Seetapan, N.; Kiatkamjornwong, S. Acrylamide-itaconic acid superabsorbent polymers and superabsorbent polymer/mica nanocomposites. Polym. Adv. Technol. 2011, 22, 635-647. [CrossRef]

136. Thakur, S.; Chaudhary, J.; Kumar, V.; Thakur, V.K. Progress in pectin based hydrogels for water purification: Trends and challenges. J. Environ. Manage. 2019, 238, 210-223. [CrossRef] [PubMed]

137. Elgadir, M.A.; Akanda, M.J.H.; Ferdosh, S.; Mehrnoush, A.; Karim, A.A.; Noda, T.; Sarker, M.Z.I. Mixed biopolymer systems based on starch. Molecules 2012, 17, 584-597. [CrossRef] [PubMed]

138. Soto, D.; Urdaneta, J.; Pernía, K.; Leõn, O.; Muñoz-Bonilla, A.; Fernandez-García, M. Removal of heavy metal ions in water by starch esters. Starch/Staerke 2016, 68, 37-46. [CrossRef]

139. Soto, D.; Urdaneta, J.; Pernia, K.; León, O.; Muñoz-Bonilla, A.; Fernández-García, M. Itaconic Acid Grafted Starch Hydrogels as Metal Remover: Capacity, Selectivity and Adsorption Kinetics. J. Polym. Environ. 2016, 24, 343-355. [CrossRef]

140. De Peña, Y.P.; López, W.; Burguera, M.; Burguera, J.L.; López-Carrasquero; Carrillo, M. Flow injection system for cadmium preconcentration on poly(octadecyl diitaconate) (PDI-18) and atomic absorption spectrometry detection. Anal. Chim. Acta 2001, 438, 259-266. [CrossRef] 
141. Ge, H.; Hua, T.; Wang, J. Preparation and characterization of poly (itaconic acid)-grafted crosslinked chitosan nanoadsorbent for high uptake of $\mathrm{Hg} 2+$ and $\mathrm{Pb} 2+$. Int. J. Biol. Macromol. 2017, 95, 954-961. [CrossRef]

142. Çavuş, S.; Gürdağ, G.L. Noncompetitive removal of heavy metal ions from aqueous solutions by poly[2-(acrylamido)-2-methyl-1-propanesulfonic acid-co-itaconic acid] hydrogel. Ind. Eng. Chem. Res. 2009, 48, 2652-2658. [CrossRef]

143. Sharma, N.; Tiwari, A. Nanomagnetite-loaded poly (acrylamide-co-itaconic acid) hydrogel as adsorbent for effective removal of Mn2+ from contaminated water. Desalin. Water Treat. 2016, 57, 5654-5672. [CrossRef]

144. Milašinović, N.; Jakovetić, S.; Knežević-Jugović, Z.; Milosavljević, N.; Lučić, M.; Filipović, J.; Kalagasidis Krušić, M. Catalyzed Ester Synthesis Using Candida rugosa Lipase Entrapped by Poly(N-isopropylacrylamide-co-itaconic Acid) Hydrogel. Sci. World J. 2014, 2014, 142123. [CrossRef] [PubMed]

145. Khan, M.; Lo, I.M.C. A holistic review of hydrogel applications in the adsorptive removal of aqueous pollutants: Recent progress, challenges, and perspectives. Water Res. 2016, 106, 259-271. [CrossRef]

146. Fucinõs, C.; Fucinõs, P.; Míguez, M.; Katime, I.; Pastrana, L.M.; Ŕua, M.L. Temperature- and $\mathrm{pH}$-sensitive nanohydrogels of poly( $\mathrm{N}$-isopropylacrylamide) for food packaging applications: Modelling the swelling-collapse behaviour. PLoS ONE 2014, 9, e87190. [CrossRef] [PubMed]

147. Călinoiu, L.-F.; Ştefănescu, B.; Pop, I.; Muntean, L.; Vodnar, D. Chitosan Coating Applications in Probiotic Microencapsulation. Coatings 2019, 9, 194. [CrossRef]

148. Trif, M.; Vodnar, D.; Mitrea, L.; Rusu, A.; Socol, C. Design and Development of Oleoresins Rich in Carotenoids Coated Microbeads. Coatings 2019, 9, 235. [CrossRef]

149. Mehtiö, T.; Anghelescu-Hakala, A.; Hartman, J.; Kunnari, V.; Harlin, A. Crosslinkable poly(lactic acid)-based materials: Biomass-derived solution for barrier coatings. J. Appl. Polym. Sci. 2017, 134. [CrossRef]

150. Cespugli, M.; Lotteria, S.; Navarini, L.; Lonzarich, V.; Del Terra, L.; Vita, F.; Zweyer, M.; Baldini, G.; Ferrario, V.; Ebert, C.; et al. Rice Husk as an Inexpensive Renewable Immobilization Carrier for Biocatalysts Employed in the Food, Cosmetic and Polymer Sectors. Catalysts 2018, 8, 471. [CrossRef]

151. Ma, L.; Feng, S.; La Fuente-Núñez, C.D.; Hancock, R.E.W.; Lu, X. Development of Molecularly Imprinted Polymers to Block Quorum Sensing and Inhibit Bacterial Biofilm Formation. ACS Appl. Mater. Interfaces 2018, 10, 18450-18457. [CrossRef]

152. Mathers, C.; Boerma, T.; Ma Fat, D. The Global Burden of Disease: 2004 Update; WHO: Geneva, Switzerland, 2008.

153. Vos, T.; Barber, R.M.; Bell, B.; Bertozzi-Villa, A.; Biryukov, S.; Bolliger, I.; Charlson, F.; Davis, A.; Degenhardt, L.; Dicker, D.; et al. Global, regional, and national incidence, prevalence, and years lived with disability for 301 acute and chronic diseases and injuries in 188 countries, 1990-2013: A systematic analysis for the Global Burden of Disease Study 2013. Lancet 2015, 386, 743-800. [CrossRef]

154. Yang, K.; Han, Q.; Chen, B.; Zheng, Y.; Zhang, K.; Li, Q.; Wang, J. Antimicrobial hydrogels: Promising materials for medical application. Int. J. Nanomed. 2018, 13, 2217-2263. [CrossRef]

155. Sun, Y.; Li, Y.; Nan, S.; Zhang, L.; Huang, H.; Wang, J. Synthesis and characterization of pH-sensitive poly(itaconic acid)-poly(ethylene glycol)-folate-poly(L-histidine) micelles for enhancing tumor therapy and tunable drug release. J. Colloid Interface Sci. 2015, 458, 119-129. [CrossRef] [PubMed]

156. Zhao, W.; Li, A.; Zhang, A.; Zheng, Y.; Liu, J. Recent Advances in Functional-Polymer-Decorated Transition-Metal Nanomaterials for Bioimaging and Cancer Therapy. ChemMedChem 2018, 13, 2134-2149. [CrossRef] [PubMed]

157. Raţă, D.M.; Chailan, J.F.; Peptu, C.A.; Costuleanu, M.; Popa, M. Chitosan: Poly(N-vinylpyrrolidone-altitaconic anhydride) nanocapsules-A promising alternative for the lung cancer treatment. J. Nanopart. Res. 2015, 17, 316. [CrossRef]

158. Milašinović, N.; Kalagasidis Krušić, M.; Knežević-Jugović, Z.; Filipović, J. Hydrogels of $\mathrm{N}$-isopropylacrylamide copolymers with controlled release of a model protein. Int. J. Pharm. 2010, 383, 53-61. [CrossRef] [PubMed]

159. Peppas, N.A.; Bures, P.; Leobandung, W.; Ichikawa, H. Hydrogels in pharmaceutical formulations. Eur. J. Pharm. Biopharm. 2000, 50, 27-46. [CrossRef]

160. Sakthivel, M.; Franklin, D.S.; Sudarsan, S.; Chitra, G.; Sridharan, T.B.; Guhanathan, S. Investigation on $\mathrm{pH} /$ salt-responsive multifunctional itaconic acid based polymeric biocompatible, antimicrobial and biodegradable hydrogels. React. Funct. Polym. 2018, 122, 9-21. [CrossRef] 
161. Pathania, D.; Verma, C.; Negi, P.; Tyagi, I.; Asif, M.; Kumar, N.S.; Al-Ghurabi, E.H.; Agarwal, S.; Gupta, V.K. Novel nanohydrogel based on itaconic acid grafted tragacanth gum for controlled release of ampicillin. Carbohydr. Polym. 2018, 196, 262-271. [CrossRef] [PubMed]

162. Petan, T.; Jarc, E.; Jusović, M. Lipid Droplets in Cancer: Guardians of Fat in a Stressful World. Molecules 2018, 23, 1941. [CrossRef] [PubMed]

163. Amjadi, S.; Hamishehkar, H.; Ghorbani, M. A novel smart PEGylated gelatin nanoparticle for co-delivery of doxorubicin and betanin: A strategy for enhancing the therapeutic efficacy of chemotherapy. Mater. Sci. Eng. C 2019, 97, 833-841. [CrossRef]

164. Nita, L.E.; Chiriac, A.P.; Bercea, M.; Ghilan, A.; Rusu, A.G.; Dumitriu, R.P.; Mititelu-Tartau, L. Multifunctional hybrid 3D network based on hyaluronic acid and a copolymer containing pendant spiroacetal moieties. Int. J. Biol. Macromol. 2019, 125, 191-202. [CrossRef]

165. Dong, K.; Lei, Q.; Qi, H.; Zhang, Y.; Cui, N.; Wu, X.; Xie, L.; Yan, X.; Lu, T. Amplification of Oxidative Stress in MCF-7 Cells by a Novel pH-Responsive Amphiphilic Micellar System Enhances Anticancer Therapy. Mol. Pharm. 2019, 16, 689-700. [CrossRef] [PubMed]

166. Heng, C.; Zhou, X.; Zheng, X.; Liu, M.; Wen, Y.; Huang, H.; Fan, D.; Hui, J.; Zhang, X.; Wei, Y. Surface grafting of rare-earth ions doped hydroxyapatite nanorods (HAp: $\operatorname{Ln}(\mathrm{Eu} / \mathrm{Tb}))$ with hydrophilic copolymers based on ligand exchange reaction: Biological imaging and cancer treatment. Mater. Sci. Eng. C 2018, 91, 556-563. [CrossRef] [PubMed]

167. Agrawal, G.; Agrawal, R.; Pich, A. Dual Responsive Poly(N-vinylcaprolactam) Based Degradable Microgels for Drug Delivery. Part. Part. Syst. Charact. 2017, 34, 1700132. [CrossRef]

168. Eroglu, B.; Dalgakiran, D.; Inan, T.; Kurkcuoglu, O.; Güner, F.S. A computational and experimental approach to develop minocycline-imprinted hydrogels and determination of their drug delivery performances. J. Polym. Res. 2018, 25, 258. [CrossRef]

169. Valente, M.; Vedelago, J.; Chacón, D.; Mattea, F.; Velásquez, J.; Pérez, P. Water-equivalence of gel dosimeters for radiology medical imaging. Appl. Radiat. Isot. 2018, 141, 193-198. [CrossRef] [PubMed]

170. O'Neill, J. Antimicrobial Resistance: Tackling a crisis for the health and wealth of nations The Review on Antimicrobial Resistance Chaired. HM Gov. Wellcome Trust 2014, 1-20. Available online: https://amr-review.org/sites/default/files/AMR\%20Review\%20Paper\%20-\%20Tackling\% 20a\%20crisis\%20for\%20the\%20health\%20and\%20wealth\%20of\%20nations_1.pdf (accessed on 02 May 2019).

171. Riga, E.K.; Vöhringer, M.; Widyaya, V.T.; Lienkamp, K. Polymer-Based Surfaces Designed to Reduce Biofilm Formation: From Antimicrobial Polymers to Strategies for Long-Term Applications. Macromol. Rapid Commun. 2017, 38. [CrossRef] [PubMed]

172. Boschert, D.; Schneider-Chaabane, A.; Himmelsbach, A.; Eickenscheidt, A.; Lienkamp, K. Synthesis and Bioactivity of Polymer-Based Synthetic Mimics of Antimicrobial Peptides (SMAMPs) Made from Asymmetrically Disubstituted Itaconates. Chemistry 2018, 24, 8217-8227. [CrossRef] [PubMed]

173. Kiso, Y.; Kosumoto, A.; Furuya, E. Use of Itaconic Acid for Regulation of Glycolytic Metabolism. European Patent EP1062954B1, 30 May 2007.

174. De Seymour, J.V.; Conlon, C.A.; Sulek, K.; Villas Bôas, S.G.; McCowan, L.M.E.; Kenny, L.C.; Baker, P.N. Early pregnancy metabolite profiling discovers a potential biomarker for the subsequent development of gestational diabetes mellitus. Acta Diabetol. 2014, 51, 887-890. [CrossRef]

175. Meiser, J.; Kraemer, L.; Jaeger, C.; Madry, H.; Link, A.; Lepper, P.M.; Hiller, K.; Schneider, J.G. Itaconic acid indicates cellular but not systemic immune system activation. Oncotarget 2018, 9, 32098-32107. [CrossRef]

176. Sakai, A.; Kusumoto, A.; Kiso, Y.; Furuya, E. Itaconate reduces visceral fat by inhibiting fructose 2,6-bisphosphate synthesis in rat liver. Nutrition 2004, 20, 997-1002. [CrossRef] [PubMed]

177. Mills, E.L.; Ryan, D.G.; Prag, H.A.; Dikovskaya, D.; Menon, D.; Zaslona, Z.; Jedrychowski, M.P.; Costa, A.S.H.; Higgins, M.; Hams, E.; et al. Itaconate is an anti-inflammatory metabolite that activates Nrf2 via alkylation of KEAP1. Nature 2018, 556, 113-117. [CrossRef] [PubMed]

178. Poillucci, R.A.; Hansen, C.J. Reducing Use of Styrene Monomer in Unsaturated Polyester Resins; TURI: Lowell, MA, USA, 2013.

179. Panic, V.V.; Seslija, S.I.; Popovic, I.G.; Spasojevic, V.D.; Popovic, A.R.; Nikolic, V.B.; Spasojevic, P.M. Simple One-Pot Synthesis of Fully Biobased Unsaturated Polyester Resins Based on Itaconic Acid. Biomacromolecules 2017, 18, 3881-3891. [CrossRef] [PubMed] 
180. European Commission. A European Strategy for Plastics in a Circular Economy; European Commission: Brussels, Belgium, 2018.

181. Fidanovski, B.Z.; Popovic, I.G.; Radojevic, V.J.; Radisavljevic, I.Z.; Perisic, S.D.; Spasojevic, P.M. Composite materials from fully bio-based thermosetting resins and recycled waste poly(ethylene terephthalate). Compos. Part B Eng. 2018, 153, 117-123. [CrossRef]

(c)

(C) 2019 by the authors. Licensee MDPI, Basel, Switzerland. This article is an open access article distributed under the terms and conditions of the Creative Commons Attribution (CC BY) license (http://creativecommons.org/licenses/by/4.0/). 